\title{
Fire Performance of an Interstitial Space Construction System
}

J. R. Lawson, E. Braun, L. DeLauter and G. Roadarmel

Building and Fire Research Laboratory

Gaithersburg, Maryland 20899

\section{United States Department of Commerce} chnology Administration

QC tional Institute of Standards and Technology

100

.056

N0. 5560

1995 



\section{Fire Performance of an Interstitial Space Construction System}

J. R. Lawson, E. Braun, L. DeLauter and G. Roadarmel

February 1995

Building and Fire Research Laboratory

National Institute of Standards and Technology

Gaithersburg, MD 20899

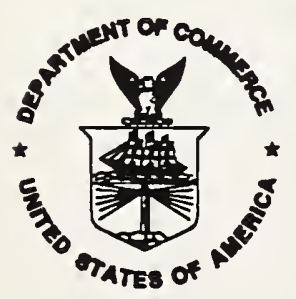

\section{U.S. Department of Commerce}

Ronald H. Brown, Secretary

Technology Administration

Mary L. Good, Under Secretary for Technology

National Institute of Standards and Technology

Arati Prabhakar, Director
Sponsored by:

Medical Facilities Office

U.S. Army Corps of Engineers

HQUSACE CEMP-EM

Washington, DC 20314-1000 



\section{TABLE OF CONTENTS}

page

LIST OF FIGURES

LIST OF FIGURES - APPENDIX B .................... vi

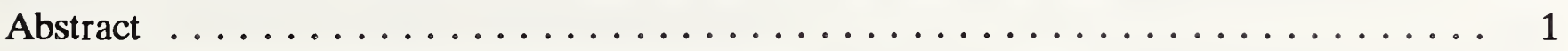

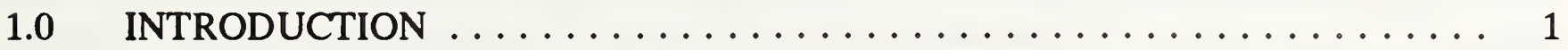

2.0 SUPPORTING TEST STRUCTURE AND FIRE TEST FURNACE $\ldots \ldots \ldots$

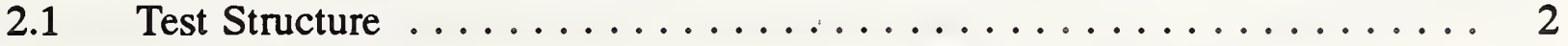

2.2 Exterior Walls Enclosing the Interstitial Space $\ldots \ldots \ldots \ldots \ldots \ldots$

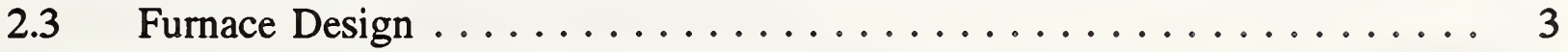

3.0 DESIGN OF CONSTRUCTION ASSEMBLY TESTED . . . . . . . . . . . . . . . 4

3.1 Description of Suspended Structural Steel System Supporting The Walk-on

Deck ............................... 4

3.2 Description of Lightweight Concrete Walk-on Deck . . . . . . . . . 4

3.3 Curing and Conditioning of The Lightweight Concrete Deck ....... 5

4.0 TEST METHOD AND TEST PRECISION $\ldots \ldots \ldots \ldots \ldots \ldots \ldots$

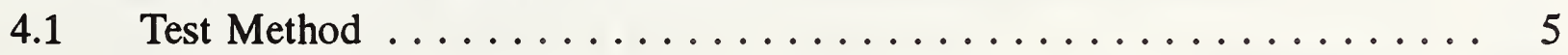

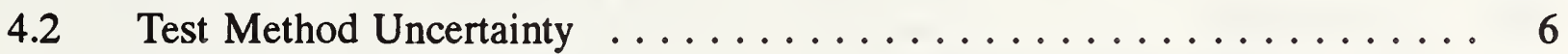

$5.0 \quad$ ACCEPTANCE CRITERIA $\ldots \ldots \ldots \ldots \ldots \ldots \ldots \ldots \ldots \ldots$

6.0 INTERSTITIAL SPACE ASSEMBLY INSTRUMENTATION $\ldots \ldots \ldots \ldots \ldots$

6.1 Thermocouple Locations Specified by NFPA $251 \ldots \ldots \ldots \ldots$

6.1.1 Top Surface of the Functional Floor . . . . . . . . . . . . . 7

6.1.2 Steel Beams Supporting the Functional Floor and Walk-on Deck .. 7

6.2 Special Instrumentation $\ldots \ldots \ldots \ldots \ldots \ldots$

7.0 FIRE TEST OF INTERSTITIAL SPACE BUILDING ASSEMBLY . . . . . . 8

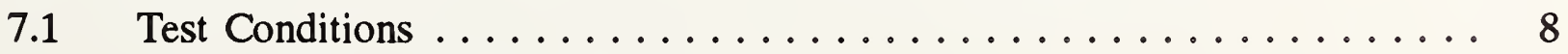

7.1.1 Walk-on Deck Moisture Content . . . . . . . . . . . . . . 8

7.1.2 Loading of The Functional Floor and Walk-on Deck ......... 8

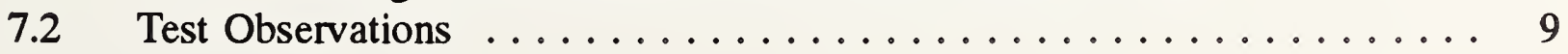

$8.0 \quad$ TEST RESULTS $\ldots \ldots \ldots \ldots \ldots \ldots \ldots \ldots \ldots \ldots \ldots \ldots \ldots \ldots$

8.1 Post Test Observations ...................... 11 
8.2 Test Data and Discussion of Results $\ldots \ldots \ldots \ldots \ldots \ldots \ldots \ldots$

8.2 .1 Test Furnace ......................... 12

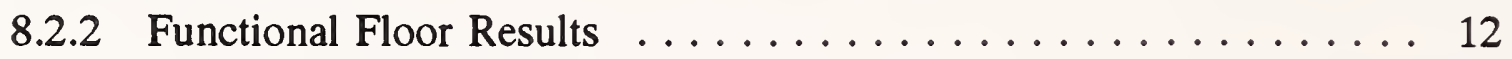

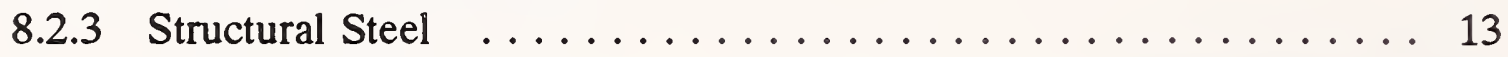

8.2.3.1 W18x35 Beams .................. 13

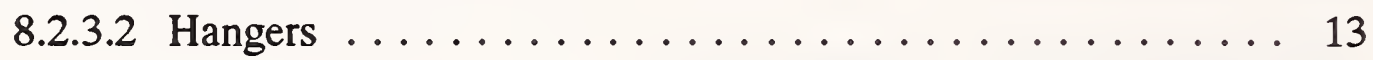

9.0 CONCLUSIONS $\ldots \ldots \ldots \ldots \ldots \ldots \ldots \ldots \ldots \ldots \ldots \ldots \ldots \ldots \ldots$

ACKNOWLEDGEMENT $\ldots \ldots \ldots \ldots \ldots \ldots \ldots \ldots \ldots \ldots \ldots \ldots \ldots \ldots \ldots$

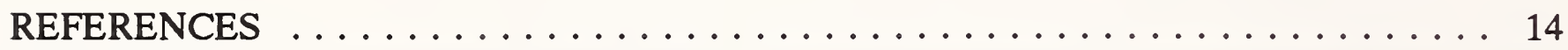

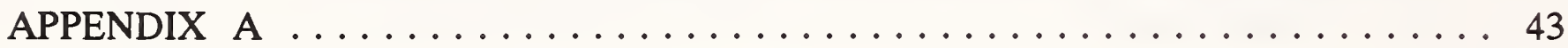

A1.0 Uncertainty Analysis . . . . . . . . . . . . . . 43

A2.0 Combined Uncertainty . . . . . . . . . . . . . . . . 44

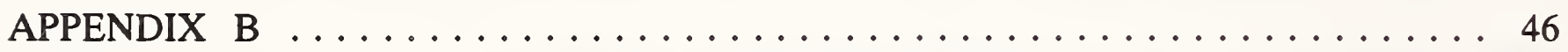

B1.0 Additional Instrumentation $\ldots \ldots \ldots \ldots \ldots \ldots \ldots \ldots \ldots \ldots \ldots$

B1.1 Top Surface of the Walk-on Deck . . . . . . . . . . . . . . . 46

B1.2 W6x9 Steel Purlins Supporting the Walk-on Deck ........... 46

B1.3 Steel Deck Supporting the Walk-on Deck ............... 46

B1.4 Thermocouples on Air Conditioning Ducts .............. 46

B1.5 Deflection Instrumentation $\ldots \ldots \ldots \ldots \ldots \ldots \ldots \ldots \ldots \ldots$

B2.0 Test Results ............................ 47

B2.1 Walk-on Deck Results ..................... 47

B2.2 Ducts and Duct Penetrations ................. 48

B2.3 Deflection Measurements .................. 48 


\section{LIST OF FIGURES}

Figure 1. Ground level plan of test structure $\ldots \ldots \ldots \ldots \ldots \ldots \ldots \ldots \ldots$

Figure 2. Photograph showing elevation of test structure $\ldots \ldots \ldots \ldots \ldots \ldots \ldots$

Figure 3. Plan of walk-on deck tested . . . . . . . . . . . . . . . . 17

Figure 4. Elevation of structural steel suspending the walk-on deck . . . . . . . . 18

Figure 5. Fabrication details for construction of structural steel assembly . . . . . . . . 19

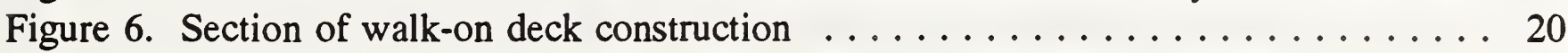

Figure 7. Horizontal supports for air conditioning ducts on walk-on deck . . . . . . . 21

Figure 8. Details of firesafing of air conditioning duct penetrations . . . . . . . . 22

Figure 9. Photograph of metal deck bracing required for pouring concrete . . . . . . . 23

Figure 10. Standard NFPA 251 time-temperature curve for test furnace . . . . . . . . . 24

Figure 11. Standard thermocouple layout for temperature measurements on functional

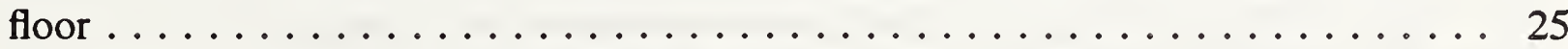

Figure 12. Thermocouple layout for $\mathrm{W} 18 \mathrm{x} 35$ beams $\ldots \ldots \ldots \ldots \ldots \ldots \ldots \ldots$

Figure 13. Photograph of load boxes placed on purlin ................ 27

Figure 14. Photograph showing damage to walk-on deck, metal decking ......... 28

Figure 15. Photograph showing damage to air conditioning duct in fire compartment . . . 29

Figure 16. Standard NFPA 251 time-temperature curve vs. actual fire test curve . . . . . . 30

Figure 17. Temperatures on surface of functional floor ............... 31

Figure 18. Temperatures on east $\mathrm{W} 18 \times 35$ beam, north end ............ 32

Figure 19. Temperatures on east $\mathrm{W} 18 \times 35$ beam, at north hanger ............ 33

Figure 20. Temperatures on east $\mathrm{W} 18 \times 35$ beam, at center $\mathrm{span} \ldots \ldots \ldots \ldots \ldots \ldots$

Figure 21. Temperatures on east $\mathrm{W} 18 \times 35$ beam, at south hanger . . . . . . . . 35

Figure 22. Temperatures on east $\mathrm{W} 18 \times 35$ beam, at south end ........... 36

Figure 23. Temperatures on west $\mathrm{W} 18 \mathrm{x} 35$ beam, at north end . . . . . . . . 37

Figure 24. Temperatures on west $\mathrm{W} 18 \mathrm{x} 35$ beam, at north hanger . . . . . . . . . . 38

Figure 25. Temperatures on west $\mathrm{W} 18 \mathrm{x} 35$ beam, at center span . . . . . . . . . 39

Figure 26. Temperatures on west $W 18 \times 35$ beam, at south hanger $\ldots \ldots \ldots \ldots \ldots 40$

Figure 27. Temperatures on west W18x35 beam, at south end ........... 41

Figure 28. Mid-height temperatures on deck hanger tubes . . . . . . . . . . 42 


\section{LIST OF FIGURES - APPENDIX B}

Figure B1. Thermocouple layout for W6x9 purlins, walk-on deck and deflection gauges ............................. 49

Figure B2. Photograph showing load bearing boxes and deflection gauge weight on purlin ................................ 50

Figure B3. Concrete slab temperatures for walk-on deck, north end location . . . . . . . 51

Figure B4. Concrete slab temperatures for walk-on deck, center location . . . . . . . 52

Figure B5. Concrete slab temperatures for walk-on deck, south end location . . . . . . . 53

Figure B6. Walk-on deck surface temperatures . . . . . . . . . . . . . . . 54

Figure B7. Temperatures on east purlin, north east quadrant location .......... 55

Figure B8. Temperatures on east purlin, south east quadrant location .......... 56

Figure B9. Temperatures on west purlin, north west quadrant location . . . . . . . . 57

Figure B10. Temperatures on west purlin, south west quadrant location ........ 58

Figure B11. Surface temperatures on simulated air conditioning ducts .......... 59 


\title{
FIRE PERFORMANCE OF AN INTERSTITIAL SPACE CONSTRUCTION SYSTEM
}

by

\author{
J.R. Lawson, E. Braun, L. DeLauter and G. Roadarmel
}

\begin{abstract}
An interstitial space building construction assembly, consisting of a walk-on deck suspended from above by structural steel which also supported a functional floor, reproduce a design planned for use in a new hospital complex at Elmendorf Air Force Base, Alaska. This interstitial space assembly was built in the multi-story steel test structure at the National Institute of Standards and Technology. The construction assembly was tested by the same protocol used to evaluate the Veteran's Administration interstitial space construction assembly, tested in 1984. This protocol followed the National Fire Protection Association's, NFPA 251 Fire Tests of Building Construction and Materials Standard, 1990 edition. Fire testing of the interstitial space system was carried out during the summer of 1994. This construction assembly met the requirements for a 2 hour fire endurance rating. The maximum surface temperature on the unexposed functional floor above the interstitial space reached $33^{\circ} \mathrm{C}\left(91^{\circ} \mathrm{F}\right)$ at the end of the two hour period. The maximum structural steel temperature inside the interstitial space was $123{ }^{\circ} \mathrm{C}$ $\left(253^{\circ} \mathrm{F}\right)$. The structural assembly was evaluated for a total of 2 hours and 30 minutes before the test was terminated.
\end{abstract}

Key Words: Fire endurance, fire research, fire tests, floor systems, interstitial spaces, structural systems

\subsection{INTRODUCTION}

Interstitial space construction systems designed to perform as a fire barrier have seen significant use since the developmental work done in 1983 by the Veteran's Administration, now the Department of Veteran's Affairs (DVA). An interstitial space design generally consists of two functional floors separated by a utility space between the floors. The interstitial space typically contains heating and air conditioning ducting, utility feed lines and piping. Fire performance of an interstitial space system primarily depends upon the performance of the walk-on deck which separates the lower functional floor space from the interstitial space. Successful walk-on deck and deck penetration designs provide acceptable levels of fire endurance for the upper functional floor while allowing for reductions in building cost. This cost savings is achieved by fewer requirements for fire-proofing of structural steel members within the interstitial space volume. With a properly designed, constructed and maintained building, using this system, most spray-on fire-proofing can be eliminated from within the interstitial space. 
This study was initiated as a result of modifications to the original Veteran's Administration design. Some of the significant changes were the larger size of structural steel members and increased spacing between the structural members. The suspension system which supports the walk-on deck also differs, and the new design used lightweight structural concrete instead of lightweight insulating concrete. Penetrations through the walk-on deck were also somewhat different. These alterations in the original design required that the new building assembly be tested to insure that it would successfully provide a 2 hour fire endurance rating. Design work on this project was coordinated through the Medical Facilities Design Office of the United States Army Corps of Engineers, in Washington, DC. Also, the Joint Commission for the Accreditation of Health Care Organizations (JCAHO) provided guidance on acceptable design criteria for the system. The United States Air Force provided funds for the study through the Corps of Engineers and monitored progress of the project. Original work on the new design and modifications was carried out by Anderson DeBartolo Pan and Rolf Jensen \& Associates, Inc. ${ }^{1}$ The National Institute of Standards and Technology, Building and Fire Research Laboratory assisted with design issues, constructed the test assembly and conducted the fire endurance test.

\subsection{SUPPORTING TEST STRUCTURE AND FIRE TEST FURNACE}

\section{$2.1 \quad$ Test Structure}

The steel structure used in evaluating the fire endurance of the new Elmendorf AFB hospital interstitial space design was the same structure used to test the Veteran's Administration (DVA) interstitial design during 1983 [1]. This test structure was originally built to replicate a corner section of a mid-height twenty story steel frame building. It was built to provide an experimental structure for a series of tests conducted by the American Iron and Steel Institute (AISI) and the National Bureau of Standards (NBS and currently NIST) [2]. A ground level plan of the structure is shown in figure 1, and the elevation is shown in the photograph of figure 2. Note: For all figures showing a plan design or instrumentation layout, north is located at the top of the drawing. The structure consists of three levels. In this test, the ground level served as the fire compartment and represented a patient floor. The second level, figure 3, consisted of the suspended walk-on deck system which formed the lower part of the interstitial space enclosure. The top level represented the functional floor which would be a patient floor in the medical facility.

This test was conducted with the fire in Test Bay \#1, as shown in figure 1. The walk-on deck had a $28.8 \mathrm{~m}^{2}\left(320 \mathrm{ft}^{2}\right)$ surface exposed to the fire compartment. The National Fire Protection Association, NFPA 251 method requires that a test floor surface area not be less than $16.2 \mathrm{~m}^{2}$

${ }^{1}$ Certain businesses, commercial equipment, instruments, or materials are identified in this paper in order to adequately specify the experimental procedure. Such identification does not imply recommendation or endorsement by the National Institute of Standards and Technology, nor does it imply that the materials or equipment identified are necessarily the best available for the purpose. 
$\left(180 \mathrm{ft}^{2}\right)$ [3]. The short concrete block walls resting on the mid-height beams shown in figure 2 were used to provide the required vertical spacing for the interstitial space. The wall construction which enclosed the interstitial space is described in section 2.2. All openings located around the test assembly and the interstitial space walls were packed with mineral fiber fire-stopping to prevent leakage of hot gases.

\subsection{Exterior Walls Enclosing the Interstitial Space}

The interstitial space was enclosed around its perimeter by a multi-layered gypsum wallboard system similar to that used with the Veteran's Administration design tested, in 1984. This system was designed to provide protection from weather on the outside and to provide fire protection to the metal stud system supporting the wall on the inside. This wall system was also constructed to resist leakage of hot gases from the interstitial space to the outside. One wall of this system was penetrated by two air conditioning ducts. These penetrations can be seen in figures 2 and 3. The wall system consisted of two layers of $12.7 \mathrm{~mm}(0.5 \mathrm{in})$ Type-X gypsum board attached to $92.1 \mathrm{~mm}$ (3.625 in) galvanized steel studs. These studs were fastened to galvanized steel track and were spaced $0.406 \mathrm{~m}(16 \mathrm{in})$ on center. The second layer of gypsum board on this interior part of the wall was turned $90^{\circ}$ to the orientation of the base layer of board. The gypsum board was attached as needed with 25.4 and $41.3 \mathrm{~mm}$ (1 and $1.625 \mathrm{in}$ ) Type "S" drywall screws. The steel studs exterior side was protected with a single layer of $12.7 \mathrm{~mm}$ ( $0.5 \mathrm{in})$ water resistant gypsum board, screw attached using $25.4 \mathrm{~mm}$ (1 in) Type "S" drywall screws. This water resistant board was then covered with sheets of 28 gage galvanized steel, attached with self-tapping sheet metal screws.

\section{$2.3 \quad$ Furnace Design}

The fire compartment for this test was located at the structure's ground level in test bay 1 on the south end of the structure. The compartment measured $4.87 \times 6.09 \mathrm{~m}(16 \times 20 \mathrm{ft})$ with a vertical measurement from the bottom of the walk-on deck test floor to ground level of approximately $3.66 \mathrm{~m}(12 \mathrm{ft})$. The furnace was enclosed with 20 gage steel sheet metal screw attached to light gage steel studs. The studs were located $406 \mathrm{~mm}(16 \mathrm{in})$ on center around the furnace's perimeter. The sheet metal enclosure was covered on the interior with a high temperature ceramic fiber blanket. All metal surfaces exposed to the furnace were covered with either the ceramic fiber blanket or spray on fire-proofing. This was done to provide protection from the intense heat and to insulate the furnace chamber to reduce heat loss. All structural steel exposed to the furnace chamber was protected by a minimum $50 \mathrm{~mm}(2 \mathrm{in})$ thick coating of spay applied cementitious fire-proofing. The furnace chamber floor consisted of a blend of soil and building sand. Building sand was used to fill any furnace openings found at ground level.

The furnace was heated by a $4.4 \mathrm{MW}(15,000,000 \mathrm{Btu} / \mathrm{h})$ propane gas burner. The furnace temperature was measured by 10 thermocouples located $305 \mathrm{~mm}(1 \mathrm{ft})$ below the bottom surface of the walk-on deck. Five of these furnace thermocouples were evenly spaced along each of the two longs sides of the test chamber. Products of combustion in the furnace chamber were vented through a stack located on the burner end of the chamber. 


\subsection{DESIGN OF CONSTRUCTION ASSEMBLY TESTED}

\subsection{Description of Suspended Structural Steel System Supporting The Walk-on Deck}

The walk-on deck assembly was suspended from above by $102 \times 102 \times 6 \mathrm{~mm}(4 \times 4 \times 1 / 4$ in) steel tubes with $13 \times 203 \times 203 \mathrm{~mm}(1 / 2$ in $\times 8$ in $\times 8$ in) steel plates placed through the center of each end of the hanger tubes. See figures 4 and 5 . The plates were welded to the tubing and to the purlins below. The plates on the upper end were welded to W18 35 steel beams which supported the entire assembly. A functional floor was located on top of the W18x35 steel beams. The W18x35 beams were placed $2.946 \mathrm{~m}(9 \mathrm{ft} 8 \mathrm{in})$ on center. The test structure's functional floor consisted of a $133 \mathrm{~mm}$ (5 1/4 in) thick normal weight $2403 \mathrm{~kg} / \mathrm{m}^{3}\left(150 \mathrm{lb} / \mathrm{ft}^{3}\right)$ concrete deck supported on a 20 gage galvanized steel deck.

\subsection{Description of Lightweight Concrete Walk-on Deck}

A $152 \mathrm{~mm}$ (6 in) thick walk-on deck constructed of $1874 \mathrm{~kg} / \mathrm{m}^{3}\left(117 \mathrm{lb} / \mathrm{ft}^{3}\right)$ lightweight concrete was supported on $51 \mathrm{~mm}$ ( 2 in), 18 gage, Type "W", galvanized steel deck which was $762 \mathrm{~mm}$ (30 in) wide. Figure 3 shows the plan and figure 6 show a cross section of the walk-on deck. The concrete was reinforced with a $127 \mathrm{~mm}$ (5 in) square mesh of \#3 rebar. With the consent of the Joint Commission for the Accreditation of Health Care Organizations (JCAHO), the \#3 rebar reinforcement was substituted for the W4x4/D9xD9 wire mesh used in the design and is considered to be equivalent. The steel decking which supports the concrete was welded to horizontal W6x9 purlins spaced $2.946 \mathrm{~m}$ (9 $\mathrm{ft} 8 \mathrm{in}$ ) on center. The purlins contained $914 \mathrm{~mm}$ ( $3 \mathrm{ft}$ ) long \#5 rebar reinforcement centered in holes drilled through the purlin web. These rebars were spaced each $305 \mathrm{~mm}$ (12 in) on center along the purlin length. The bottom of each W6x9 purlin which extended into the fire chamber was coated with a spray on $2 \mathrm{hr}$ fire-proofing. The purlin fire-proofing was reinforced with galvanized steel wire mesh twisted to form $50 \mathrm{~mm}(2 \mathrm{in})$ hexagons. Two $356 \mathrm{~mm}$ (14 in) diameter penetrations were located in the walk-on deck. See figure 3. These penetrations provided for the passage of two $305 \mathrm{~mm}$ (12 in) diameter 22 gage steel sheet metal ducts through the walk-on deck. The ducts were supported on the walk-on deck as shown in figure 7. The penetrations were sealed with mineral fiber firesafing wrapped $50 \mathrm{~mm}$ ( 2 in) thick around the ducts with a material having a $64.07 \mathrm{~kg} / \mathrm{m}^{3}\left(4 \mathrm{lb} / \mathrm{ft}^{3}\right)$ density, $\mathrm{k}$ factor no greater than $0.0346 \mathrm{~W} / \mathrm{mK}\left(0.24 \mathrm{Btu}-\mathrm{in} /\left(\mathrm{h}-\mathrm{ft}^{2}-^{\circ} \mathrm{F}\right)\right)$, and melt point no less than $1093{ }^{\circ} \mathrm{C}$ $\left(2000^{\circ} \mathrm{F}\right)$. See figure 8 . The firesafing was installed from below and positioned $102 \mathrm{~mm}(4 \mathrm{in})$ up into the deck opening and extended $76 \mathrm{~mm}$ ( 3 in) below the walk-on deck into the fire chamber. Two bands of 16 gage steel tie wire secured the firesafing to the duct in the fire chamber. The firesafing was then topped to floor surface level with a $50 \mathrm{~mm}(2 \mathrm{in})$ thick finish of smoke barrier sealant. One of the two ducts was covered with $50 \mathrm{~mm}\left(2\right.$ in) thick, $12 \mathrm{~kg} / \mathrm{m}^{3}$ $\left(3 / 4 \mathrm{lb} / \mathrm{ft}^{3}\right)$ density mineral fiber insulation which simulated an installed air-conditioning supply duct. Circular steel air diffusers were attached to the duct ends extending into the fire chamber.

During construction of this assembly, just before the concrete was poured, the test assembly building contractor expressed a concern that the $2.946 \mathrm{~m}$ (9 ft $8 \mathrm{in}$ ) metal deck span was weak, 
especially at center span, and may not safely support the concrete load. Wood bracing was erected under the metal deck's center portion to give the needed support for pouring the concrete. The wood bracing was removed after the concrete had set. Figure 9 shows a photograph of the deck bracing.

\subsection{Curing and Conditioning of The Lightweight Concrete Deck}

The $1874 \mathrm{~kg} / \mathrm{m}^{3}\left(117 \mathrm{lb} / \mathrm{ft}^{3}\right)$ lightweight structural concrete which formed the walk-on deck was poured on April 20,1994. The day was sunny, and the temperature at the time of pouring was $20^{\circ} \mathrm{C}\left(68^{\circ} \mathrm{F}\right)$. Samples of concrete were taken and tested by a commercial independent testing laboratory to determine consistency of the mix and compressive strength of the set concrete. An ASTM C143 slump measurement test was performed on the concrete mix as it was coming from the delivery truck [4]. This slump measurement was $152 \mathrm{~mm}$ (6 in). In addition, four concrete cylinder samples were taken in accordance with ASTM C31 and tested in accordance with ASTM C39 [5][6]. These cylinders measured $152 \mathrm{~mm} \mathrm{x} 305 \mathrm{~mm}$ (6 in x $12 \mathrm{in}$ ). The cylinder samples were laboratory cured before testing. The seven day tests of two cylinders provided compressive strength values of 22.68 and $23.30 \mathrm{MPa}(3,290$ and 3,380 psi). The 28 day samples had values of 33.92 and $33.44 \mathrm{MPa}(4,920$ and 4,850 psi).

After the concrete deck had completed its normal 28 day curing time, two kerosene fired, blower driven space heaters were placed into the test structure's furnace chamber. These heaters were typically run for periods of 16 to 24 hours a day from May 19, 1994 until June 20, 1994. Air temperature below the walk-on deck was generally maintained at $54^{\circ} \mathrm{C}\left(130^{\circ} \mathrm{F}\right)$. This was done to accelerate the rate of moisture loss from the slab. Concrete core samples were taken for measuring moisture content of the slab. Results from these samples are found in section 7.1.1 which describes the concrete deck's moisture content just prior to testing.

\subsection{TEST METHOD AND TEST PRECISION}

\subsection{Test Method}

The interstitial space assembly was tested using procedures developed for the Veteran's Administration (DVA) interstitial space tests conducted in 1983 and following the procedure documented in, NFPA 251, Fire Tests of Building Construction and Materials 1990 Edition. This standard test method is intended to evaluate the duration for which a, generally closely coupled, floor/ceiling or wall assembly will contain a fire. And, it is also used to evaluate if a structural element or system will retain its integrity. The test exposes a construction assembly or element to a standard time-temperature exposure to determine fire endurance. In this test, as well as with the Veteran's Administration (DVA) test, the complexity of an interstitial space design resulted in the evaluation of several different structural elements and systems at once. With the standard NFPA 251 test, fire endurance of structural beams, air conditioning duct penetrations, and heat transmission through a floor assembly may be evaluated separately. In this study all system elements were evaluated during a single test. 
The fire exposure for this test was provided by a single $4.4 \mathrm{MW}(15,000,000 \mathrm{Btu} / \mathrm{h})$ propane gas burner located in the fire compartment below the walk-on deck floor. A plot of the standard time-temperature curve used in NFPA 251 is shown in figure 10. The same time-temperature curve was used for evaluation of the Veterans Administration (DVA) interstitial space designs tested in 1983, reported in NBSIR 85-3158 "Fire Performance of Interstitial Space Construction Systems." For this test, NIST used the same steel test structure and facilities as were reported in the Veterans Administration (DVA) tests.

\subsection{Test Method Uncertainty}

Even though NFPA 251 is a widely used test method and has been employed for several decades, no statement of expected precision has been prepared for the standard. This may be attributed to the fact that NFPA 251 tests are generally quite costly and replicate tests are not typically conducted. Usually, only one test is conducted to evaluate a large construction assembly. Duplicate tests are typically run only to evaluate improvements to a design which may have failed an earlier test. In addition, little has been done to quantify the expected variability or accuracy of the systems used to conduct the test. For these reasons, the uncertainty statement for this study is limited to instrument uncertainty during the test. Additional information on the effects of changes in test design and conduct are discussed by Babrauskas [7].

Within the standard fire endurance test are two parameters which are measured for controlling the construction system's thermal exposure. These are the measurement of time and temperature. Experimental uncertainty for NFPA 251 is related explicitly to the uncertainty of time measurement and implicitly to uncertainties associated with temperature measurements of critical assembly components and furnace temperatures.

Two basic elements are identified as being significant in the assessment of instrument uncertainty with this test:

1. Time measurement - This is broken down into two components, computer clock accuracy and data acquisition delay time associated with the time between reading the computer clock and reading a thermocouple output.

2. Temperature measurement - Three elements relate to uncertainty in temperature measurements were considered: Inherent accuracy of thermocouple materials, mathematical accuracy of voltage to temperature conversion, and accuracy of the instrument used to measure thermocouple voltages.

Appendix A of this report contains an uncertainty analysis for representative time and temperature measurements made during this test. From this analysis, it was determined that the maximum instrument uncertainty for the total fire-endurance period of two hours thirty minutes was 9 percent. 


\subsection{ACCEPTANCE CRITERIA}

The same ignition and temperature acceptance criteria for the VA tests were applied to the proposed Elmendorf Air Force Base Hospital design. The following acceptance criteria for this test are based on NFPA 251 and were selected by the sponsor:

The functional floor shall have sustained an applied load of $45.4 \mathrm{~kg} / \mathrm{m}^{2}\left(100 \mathrm{lb} / \mathrm{ft}^{2}\right)$ without developing surface conditions that will ignite cotton waste.

The average temperature on the top surface of the functional floor shall not rise more than $121^{\circ} \mathrm{C}\left(250^{\circ} \mathrm{F}\right)$ above ambient conditions.

The temperature of the steel beams or hangers within the interstitial space shall not exceed $704{ }^{\circ} \mathrm{C}\left(1300{ }^{\circ} \mathrm{F}\right)$ at any location during the test, nor shall the average temperature recorded by four thermocouples at any section have exceeded $593{ }^{\circ} \mathrm{C}$ $\left(1100^{\circ} \mathrm{F}\right)$ during the test.

\subsection{INTERSTITIAL SPACE ASSEMBLY INSTRUMENTATION}

\subsection{Thermocouple Locations Specified by NFPA 251}

The acceptance criteria specified in section 5.0 required that test thermocouples be positioned at definite locations in the test structure. The two areas were the functional floor and the unprotected structural steel supporting the functional floor. Details on this instrumentation are found in the next two subsections.

\subsubsection{Top Surface of the Functional Floor}

Five $0.5 \mathrm{~mm}, 24$ gage, bare bead, type $\mathrm{K}$ thermocouples were positioned on the top surface of the functional floor. These required thermocouples were located as shown in figure 11. Each thermocouple was covered with a $152 \mathrm{~mm}(6$ in) square $10 \mathrm{~mm}(0.375$ in) thick refractory fiber pad which met the requirements of Appendix C of NFPA 251.

\subsubsection{Steel Beams Supporting the Functional Floor and Walk-on Deck}

Each of the two W18x35 steel beams used to support the functional floor had five groups of four stainless steel sheathed, $3 \mathrm{~mm}(0.125 \mathrm{in})$ diameter, type $\mathrm{K}$ thermocouples spaced as shown in figure 12. Locations of these thermocouples are shown in elevation in figure 4. Two patterns were used for positioning the thermocouples as a result of the steel hanger tube locations. Pattern "A" was used for unobstructed runs of steel. Pattern "B" was used for the steel plate and hanger tube attachment. A total of 20 thermocouples were attached to each of the W18x35 steel beam assemblies. These thermocouples were attached using the following procedure: Holes slightly larger in diameter than the thermocouple were drilled approximately $3 \mathrm{~mm}(0.125 \mathrm{in})$ deep into the steel members at the specified locations. The thermocouple ends were inserted into the holes 
and metal to the side of each hole was peened with a punch and hammer to secure the thermocouples.

\subsection{Special Instrumentation}

Additional instrumentation was added to the interstitial space test assembly to better define overall performance of the system. Information on this instrumentation and data obtained from these measurements are presented in Appendix B of this report.

\subsection{FIRE TEST OF INTERSTITIAL SPACE BUILDING ASSEMBLY}

\subsection{Test Conditions}

The interstitial space construction system, proposed for the Elmendorf Air Force Base Hospital, was tested on June 28, 1994 using the NFPA 251 fire endurance test procedure. The test was conducted at the NIST, Building and Fire Research Laboratory steel structure facility located at it's Gaithersburg, MD Annex. The test day was partly cloudy with a light variable wind of about $2.2 \mathrm{~m} / \mathrm{s}(7.3 \mathrm{ft} / \mathrm{s})$ and a temperature of $24^{\circ} \mathrm{C}\left(75^{\circ} \mathrm{F}\right)$.

\subsubsection{Walk-on Deck Moisture Content}

As mentioned in section 3.3, core samples were removed from the walk-on deck to document the slab's moisture content before conducting the fire endurance test. These $50 \mathrm{~mm}$ ( 2 in) diameter samples measuring approximately $50 \mathrm{~mm}$ ( $2 \mathrm{in}$ ) long were taken from locations around the slabs perimeter. Locations were selected to provide a representative sample of the deck and not cause damage which would result in deck failure. Core sample holes were filled with vermiculite before the fire endurance test was conducted. Three core samples were taken on June 15, 1994 and were dried to constant weight in a $100^{\circ} \mathrm{C}\left(212^{\circ} \mathrm{F}\right)$ furnace. Deck sample moisture content was calculated based on the manufacturer's original moisture content for the concrete mix. The three sample values were $70.0,48.2$ and $49.6 \%$ with an average of $55.9 \%$. Two additional samples were taken on June 27, 1994. These samples had values of 54.0 and $58.4 \%$ with an average of $56.2 \%$. This average value, $56.2 \%$, was taken as the concrete slab's moisture content at the time of test.

\subsubsection{Loading of The Functional Floor and Walk-on Deck}

The functional floor's load requirement was $45.4 \mathrm{~kg} / \mathrm{m}^{2}\left(100 \mathrm{lb} / \mathrm{ft}^{2}\right)$. This was accomplished by locating $75,0.208 \mathrm{~m}^{3}$ (55 gal) steel drums on the $28.8 \mathrm{~m}^{2}\left(320 \mathrm{ft}^{2}\right)$ area of functional floor above the interstitial space, as shown in figure 2. A total of $14,515 \mathrm{~kg}(32,000 \mathrm{lb})$ of water was distributed among the drums to provide the required structural load. The walk-on deck purlins were loaded with a weight of $11.3 \mathrm{~kg} / \mathrm{m}^{2}\left(25 \mathrm{lb} / \mathrm{ft}^{2}\right)$, as required. This was done in the same manner as was used with the Veteran's Administration tests, in 1983 [1]. Plywood boxes were constructed in a way to fit on top of the purlin's surface. They were evenly positioned along the 
purlin's length and filled to the weight required with dry building sand. The load bearing sand boxes are shown in figure 13. The bottom of each box was insulated with calcium silicate board to prevent it from igniting during the test.

\subsection{Test Observations}

The following observations were made during the fire endurance test:

Elapsed

Time,

h:min:s

00:00:00

00:01:00

00:03:10

00:04:15

00:05:25

00:07:00

00:08:06

00:09:00

$00: 10: 33$

$00: 13: 30$

$00: 16: 10$

00:20:00

\section{TEST OBSERVATIONS}

Test begins at 11:50 a.m., June 28, 1994

Ignition

Looking into the fire chamber:

Small chips of spray-on fire-proofing are dropping off the bottom of metal deck near the purlins.

The metal deck joints are opening on the long span between the purlins. The openings are about $50 \mathrm{~mm}$ ( 2 in). Short span metal deck joints show no openings.

Metal decking joints on the long span are continuing to open. The center section of the visible spans are now open about $75 \mathrm{~mm}$ ( $3 \mathrm{in})$.

Test furnace is operating nominally on the standard time-temperature curve.

Viewing interstitial space through window:

Everything looks normal in the interstitial space except for a little water vapor (steam) and possibly some smoke. It appears that the ducts have expanded and moved somewhat. A small amount of light is noted around the outside wall seal for the short, return duct.

A bump sound is heard coming from the deck assembly.

Duct penetrations through the walk-on deck look normal.

Looking into the fire chamber:

Small flakes of fire-proofing are continuing to fall from around the purlins. The long span metal deck joints have opened to at least a $100 \mathrm{~mm}$ (4 in) separation at the joint. The short metal deck spans show no openings at the joints.

Viewing interstitial space through window:

Duct penetrations continue to appear to be tight. No noticeable smoke or hot gases appear around the duct penetrations.

Light water vapor and smoke in the interstitial space. One can still see completely across the compartment.

Looking into the fire chamber:

Fire-proofing is dropping away from the furnace steel work in the front left corner above the stack vent opening. 
00:22:02

00:23:00

00:26:00

00:32:30

00:38:04

$00: 42: 27$

$00: 45: 56$

$00: 47: 59$

00:55:00

00:58:54

01:00:50

01:09:00

01:22:02

01:24:10

01:34:00

01:37:00

01:41:40

01:43:00

01:46:06

01:48:13

01:52:00

01:54:00

02:00:00

02:06:04

Fire-proofing is continuing to fall from test structural steel work in front left corner.

Bumping sound heard near the front (south) end of the interstitial space deck.

Viewing interstitial space through window:

Visibility in the interstitial space is becoming poor. The space is filling with water vapor and smoke.

Looking into the fire chamber:

Fire-proofing appears to be still covering all purlin surfaces.

Observations of the walk-on deck, ducts and duct penetrations in the fire chamber are unchanged.

Furnace wall channel cap on west wall is now exposed. Fire-proofing has been lost and some bowing is noted in the channel.

Burner flame out. Electric gas safety valve has closed. Unknown cause. Burner reset and running again.

Fire compartment temperature is coming back on standard curve.

Burner flame out. Electrical drop out $(120 \mathrm{~V})$. Ground-fault circuit breaker activated.

Burner reset and running again.

Fire-proofing is falling off of the east purlin.

Additional fire-proofing is dropping off of east purlin. Wire mesh is showing and is hanging in one place.

West purlin appears to have all of its fire-proofing still in place.

No changes have occurred on the bottom of the interstitial space deck exposed to the fire.

Fire-proofing on west purlin still in place.

There appears to be a small deflection in the walk-on deck on the north end, center slab.

Fire-proofing falling away from east purlin. A one meter $(3.3 \mathrm{ft})$ long clear spot is noted on the purlin where bare metal is showing.

West purlin loosing fire-proofing on north end. No exposed metal is showing on this purlin.

West purlin fire-proofing in dropping off. A length of about $0.46 \mathrm{~m}$

$(1.5 \mathrm{ft})$ on the west purlin has lost all of its fire-proofing exposing a section on the north end.

Observing the interstitial space level:

A large volume of water vapor is coming from the interstitial space.

Looking into the fire chamber:

Bottom of walk-on deck unchanged from previous observations.

Fire-proofing is dropping off of west purlin again. A section about $2 \mathrm{~m}$ $(6.6 \mathrm{ft})$ long now shows bare metal.

Fire-proofing still dropping off east and west purlins exposing additional bare metal. 
Fire-proofing continues to drop off of each purlin. Metal decking is still showing a $100 \mathrm{~mm}(4 \mathrm{in})$ opening between the joints. Short span metal deck sections show no joint openings.

$02: 10: 00$

West purlin shows approximately $3 \mathrm{~m}(9.9 \mathrm{ft})$ of exposed metal.

02:22:01

Fire-proofing is still dropping off of the west purlin. The east purlin appears to have lost all of its fire-proofing.

02:25:00

West purlin is continuing to lose fire-proofing and some of the wire mesh is hanging from the purlin.

02:30:00

Burner is shut down. End of Test.

\subsection{TEST RESULTS}

\section{1 $\quad$ Post Test Observations}

The following observations were made on June 30,1994 , two days after the fire test. Two days were allowed for the test structure to cool so it could be safely entered.

Bottom of Walk-On Deck Exposed to Fire:

- $\quad$ All of the $2.946 \mathrm{~m} \mathrm{(9} \mathrm{ft} 8 \mathrm{in}$ ) steel metal decking had separated along the lapped joints.

- After cooling, the metal deck lap joints had generally returned to a position which showed openings of about a $25 \mathrm{~mm}$ (1 in). Figure 14.

- $\quad$ All $965 \mathrm{~mm}$ (3 $\mathrm{ft} 2$ in) metal deck spans appeared to show little damage with no noted joint openings.

- $\quad$ All fire-proofing had dropped away from both purlins. Bare metal was exposed along the full length of each purlin.

- The duct work which extended into the fire chamber showed significant damage. Large blisters were seen on all surfaces not covered with firesafing. Figure 15.

- $\quad$ All firesafing around the ducts and in the penetrations appeared to be in place.

Interstitial Space Observations:

- $\quad$ No large cracks were apparent in the walk-on deck inside the interstitial space. Small cracks were seen across the $2.946 \mathrm{~m}$ ( $9 \mathrm{ft} 8 \mathrm{in}$ ) width of the concrete span.

- $\quad$ Firesafing and smoke barrier around the duct penetrations appeared to be in place.

- The purlins may have moved some, but appear to be straight.

- The walk-on deck slab appeared to have pulled away form its normal position toward the center. The deck appeared to be sagging in the center, and there was increased space around the edges of about $50 \mathrm{~mm}(2 \mathrm{in})$.

- The thermal insulation wrapped around the supply AC duct was discolored "brown" near the floor penetration.

The $102 \times 102 \times 6.4 \mathrm{~mm}(4 \times 4 \times 1 / 4$ in) steel hanger tubes and the W18x35 steel beams appear to be unaffected by the fire test. 
- $\quad$ Paper on the east gypsum board wall enclosing the interstitial space was burned away over about a $1.2 \mathrm{~m}\left(4 \mathrm{ft}^{2}\right)$ area near the walk-on deck supply duct.

- $\quad$ No fire exposure damage was noticeable at any of the five concrete core drill locations on the walk-on deck.

Functional Floor Observations:

- No changes were noted in the functional floor relative to its pretest condition.

\subsection{Test Data and Discussion of Results}

This section contains information concerning requirements for successful NFPA 251 test operations and addresses the acceptance criteria for the interstitial space construction assembly. Additional test results are presented in Appendix B of this report for instrumentation not directly related to the acceptance criteria.

\subsubsection{Test Furnace}

In accordance with section 2-2.3 of NFPA 251 , the test assembly was exposed to an acceptable fire test environment required for a two hour rating. Figure 16 shows the standard timetemperature curve along with the actual temperature curve as measured during the fire test. The total furnace exposure was for 2 hours and 30 minutes. The area under the curve for the test was $104,360{ }^{\circ} \mathrm{C}$-min as compared to the standard NFPA 251 area of $105,430{ }^{\circ} \mathrm{C}$-min which was a difference of 1.01 percent. The main reason for the area differences resulted from two electrical failures during the test which caused the burner to shut down. These drops can be seen in figure 16. In each case, the burner was restarted within 2 minutes. Section 2-2.3 of the NFPA 251 standard allows an area difference of 7.5 percent between the actual test area and the standard time-temperature curve area for a two hour test. For tests longer than two hours, a difference of 5.0 percent is allowed.

\subsubsection{Functional Floor Results}

Temperature measurements for the functional floor's surface are shown in figure 17. These plots show that maximum temperature rise for the two hour test period was no greater than $33{ }^{\circ} \mathrm{C}$ $\left(91^{\circ} \mathrm{F}\right)$. No changes in floor temperature were noted until about 60 minutes into the test. At that point, temperatures generally began to rise across the deck. The center position thermocouple temperature becomes less than the others at about 75 minutes into the test. This is attributed to heat losses to a structural steel member located near the thermocouple. The maximum temperature rise above ambient for the functional floor's surface was $22^{\circ} \mathrm{C}\left(72{ }^{\circ} \mathrm{F}\right)$ at the end of 2 hours and 30 minutes. The functional floor used in this test was the same one 
used in the 1983 tests conducted for the Veteran's Administration. This floor had aged for eleven years and was considered to be free of excess moisture. No cracks attributed to this test were noted on the surface. It is also apparent from the temperatures within the interstitial space and the functional floor's surface temperatures that no gases capable of igniting cotton waste passed through the floor.

\subsubsection{Structural Steel}

\subsubsection{W18x35 Beams}

Figures 18-22 give temperature data plots for the W18x35 beam located on the east side of the test assembly. The temperatures show that the beam was protected by the walk-on deck. All temperatures on the east beam remained less than $100^{\circ} \mathrm{C}\left(212^{\circ} \mathrm{F}\right)$ over an elapsed time of 1 hour 50 minutes. At about 2 hours into the test, temperatures exceeded $100^{\circ} \mathrm{C}\left(21{ }^{\circ} \mathrm{F}\right)$ on the beam at the center span position. For a two hour fire endurance rating, these temperatures are more than $590{ }^{\circ} \mathrm{C}\left(1094^{\circ} \mathrm{F}\right)$ below the single-point failure temperature, $704{ }^{\circ} \mathrm{C}\left(1300{ }^{\circ} \mathrm{F}\right)$.

Figures 23-27 provide temperature measurements for the W18x35 beam located on the west side of the test assembly. Temperatures on these beams were generally slightly less than those on the east beam. It is also noted that temperatures showed more fluctuation for the measurement points at the beam's center, south west hanger and south end. These temperature variations coincide with that seen with the south west hanger discussed in section 8.2.3.2. The maximum recorded temperature for this beam was $123^{\circ} \mathrm{C}\left(253^{\circ} \mathrm{F}\right)$. Again, this likely resulted from changing air flow conditions within the interstitial space as the walk-on deck and enclosing walls moved.

\subsubsection{Hangers}

Figure 28 gives the temperature plots for the four mid-height thermocouples attached to the steel tube hangers which suspended the walk-on deck. As can be seen, the four hanger tubes easily passed the test with temperatures only slightly higher than $110^{\circ} \mathrm{C}\left(230^{\circ} \mathrm{F}\right)$. The single point failure temperature for steel is $704^{\circ} \mathrm{C}\left(1300^{\circ} \mathrm{F}\right)$. At about 75 minutes into the test, the south west quadrant hanger experienced some temperature variations. This may have resulted from changing air flow patterns within the interstitial space as the walk-on deck and enclosing walls began to move. After thirty minutes of variation, the hanger temperature stabilized and continued in a more uniform fashion for the remainder of the test.

\subsection{CONCLUSIONS}

The interstitial space building construction assembly tested in this study has achieved a minimum two hour fire endurance rating based on temperature limits specified by NFPA 251 . Neither the unprotected steel in the interstitial space nor the functional floor supported by these structural 
steel members approached a failure condition. Fire-proofing with a two hour rating is required for protecting the W6x9 steel purlins. Performance of this construction system may be significantly different if the purlin fire-proofing does not maintain its integrity. The firesafing methods used to protect duct penetrations met the requirements for a two hour system. This design prevented the passage of hot gases into the interstitial space. The air conditioning ducts maintained their integrity throughout the complete test period. As with the Veteran's Administration tests in 1983, the ducts were sealed on the unexposed end which did not allow hot gases to flow through. The steel decking used to support the lightweight concrete walk-on deck showed significant degradation early in the test. Decking joints opened across the long span between the W6x9 purlins.

\section{ACKNOWLEDGEMENT}

Appreciation is extended to the following people that provided assistance with this study:

Mr. Paul W. Hanreeder and Mr. Philip Hoge of the U.S. Army Corps of Engineers; Capt. Kevin S. Purvis, Headquarters USAF/CEC; Mr. Donald C. Moeller, P.E., Rolf Jensen \& Associates, Inc.; Mr. Donald M. Drakulich and Mr. Vernon Rosamond, AIA, Anderson DeBartolo Pan; Mr. Rob Mapp, Genstar Technical Center; Mr. Frank Davis and Mr. John Gross, NIST, Building and Fire Research Laboratory. Golden Eagle Construction Company, Inc. assisted with construction of the interstitial space system.

\section{REFERENCES}

[1] Lawson, J. Randall, Fire Performance of Interstitial Space Construction Systems, National Bureau of Standards (U.S.), NBSIR 85-3158, 1985.

[2] Jeanes, D.C., Predicting Fire Endurance of Steel Structures, paper presented to American Society of Civil Engineers, April 1982.

[3] Standard Methods of Fire Tests of Building Construction and Materials, NFPA 251, National Fire Protection Association, Quincy, MA, 1990.

[4] Standard Test Method for Slump of Hydraulic Cement Concrete, ASTM C143-90a, American Society of Testing and Materials, Philadelphia, PA, 1990.

[5] Standard Test Methods of Making and Curing Concrete Test Specimens in the Field, ASTM C31-91, American Society of Testing and Materials, Philadelphia, PA, 1991.

[6] Standard Test Method for Compressive Strength of Cylindrical Concrete Specimens, ASTM C39-86 ${ }^{\mathrm{e} 1}$, American Society of Testing and Materials, Philadelphia, PA, 1990.

[7] Babrauskas, V., Fire Endurance in Buildings, PhD thesis, University of California, Berkeley, 1976. 


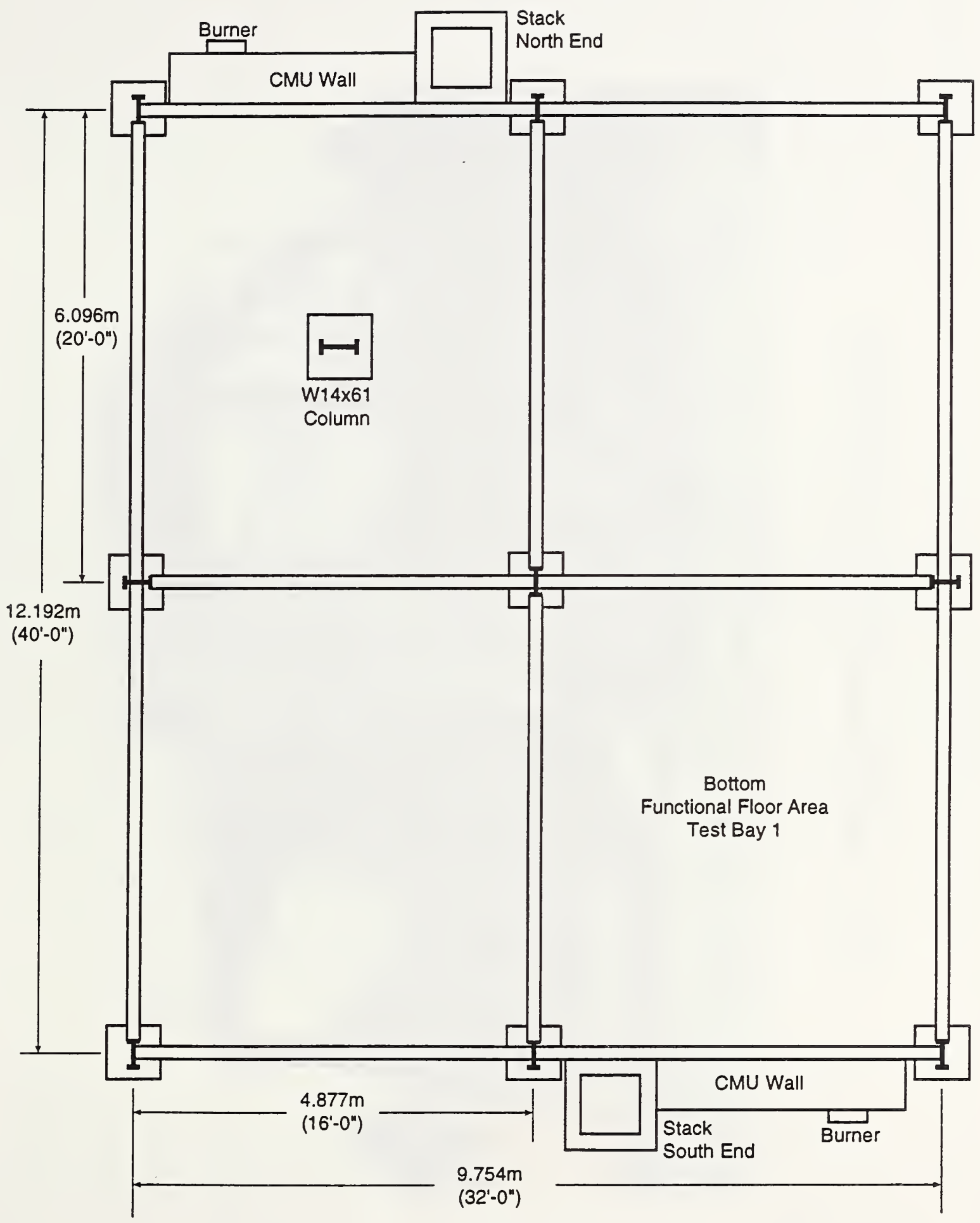

Figure 1. Ground level plan of test structure 



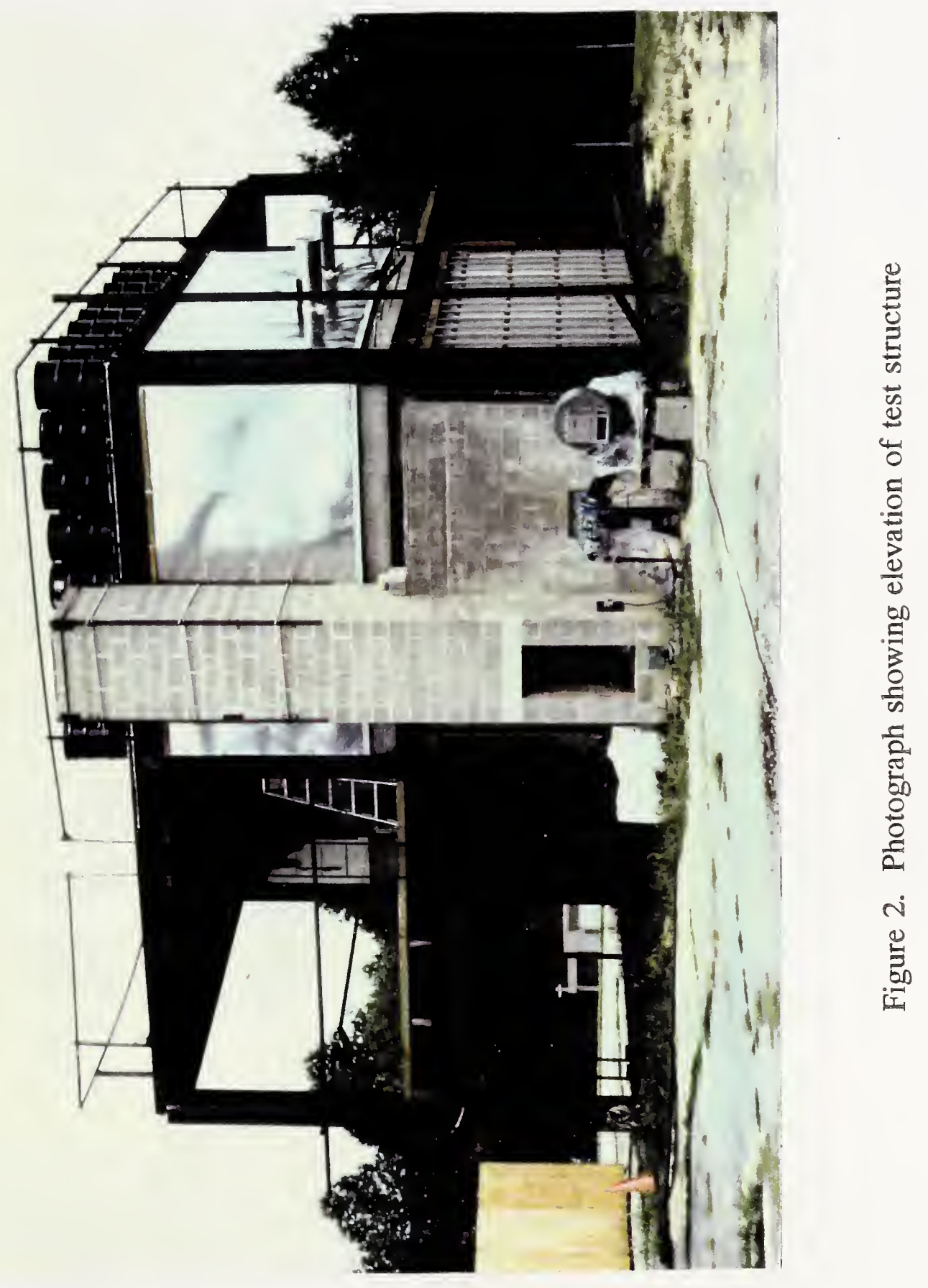



- Thermocouple Locations

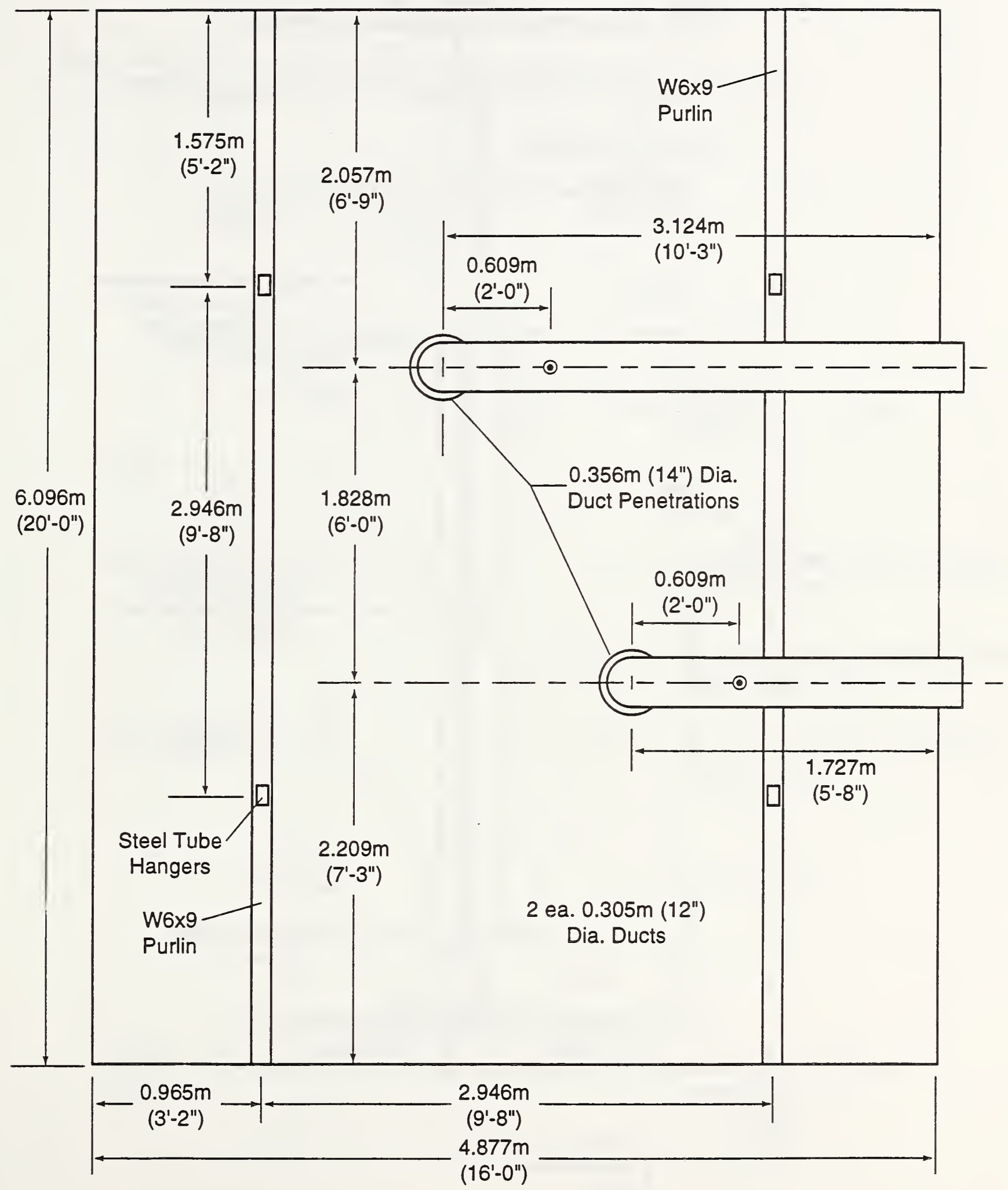

Figure 3. Plan of walk-on deck tested 


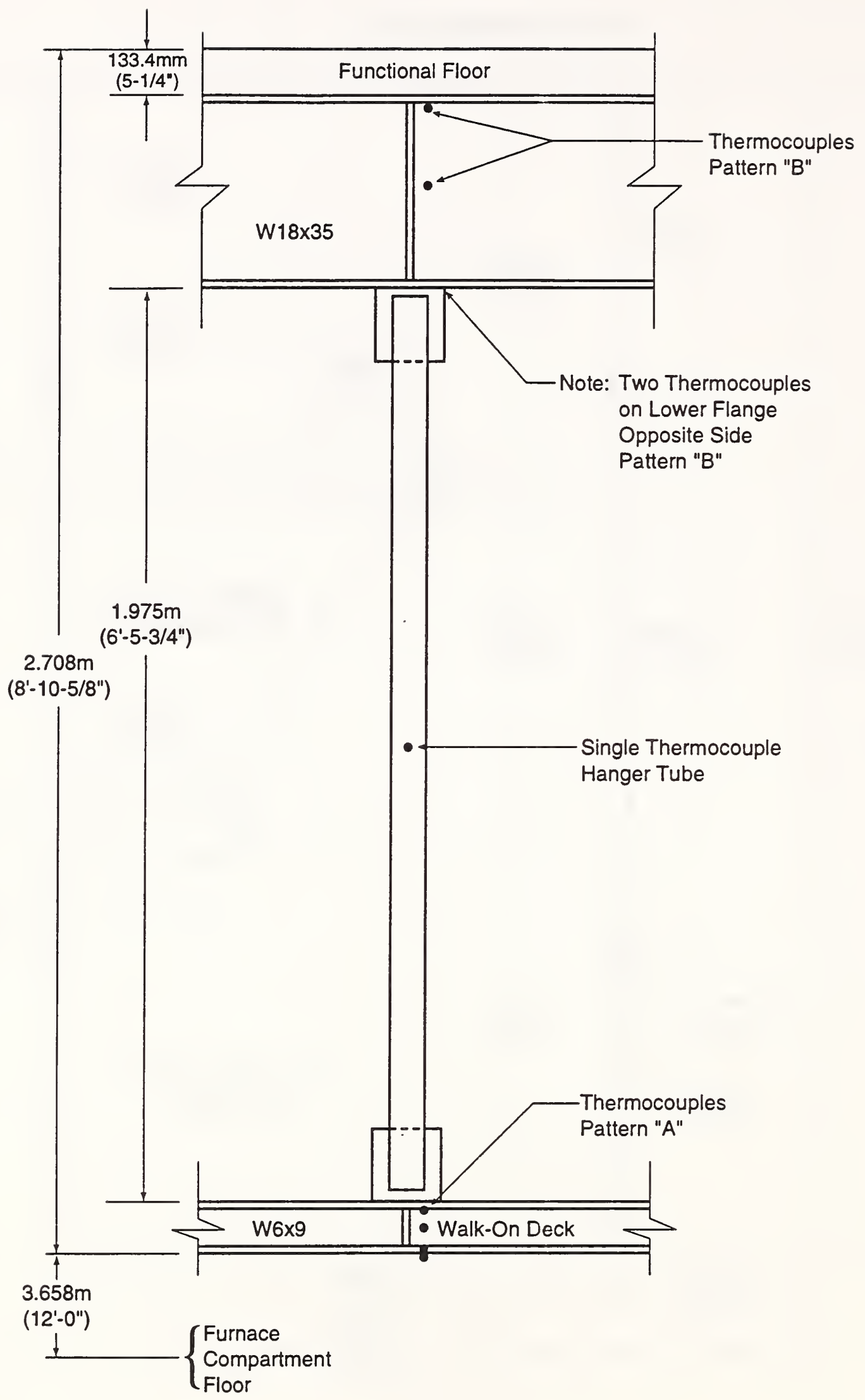

Figure 4. Elevation of structural steel suspending the walk-on deck 


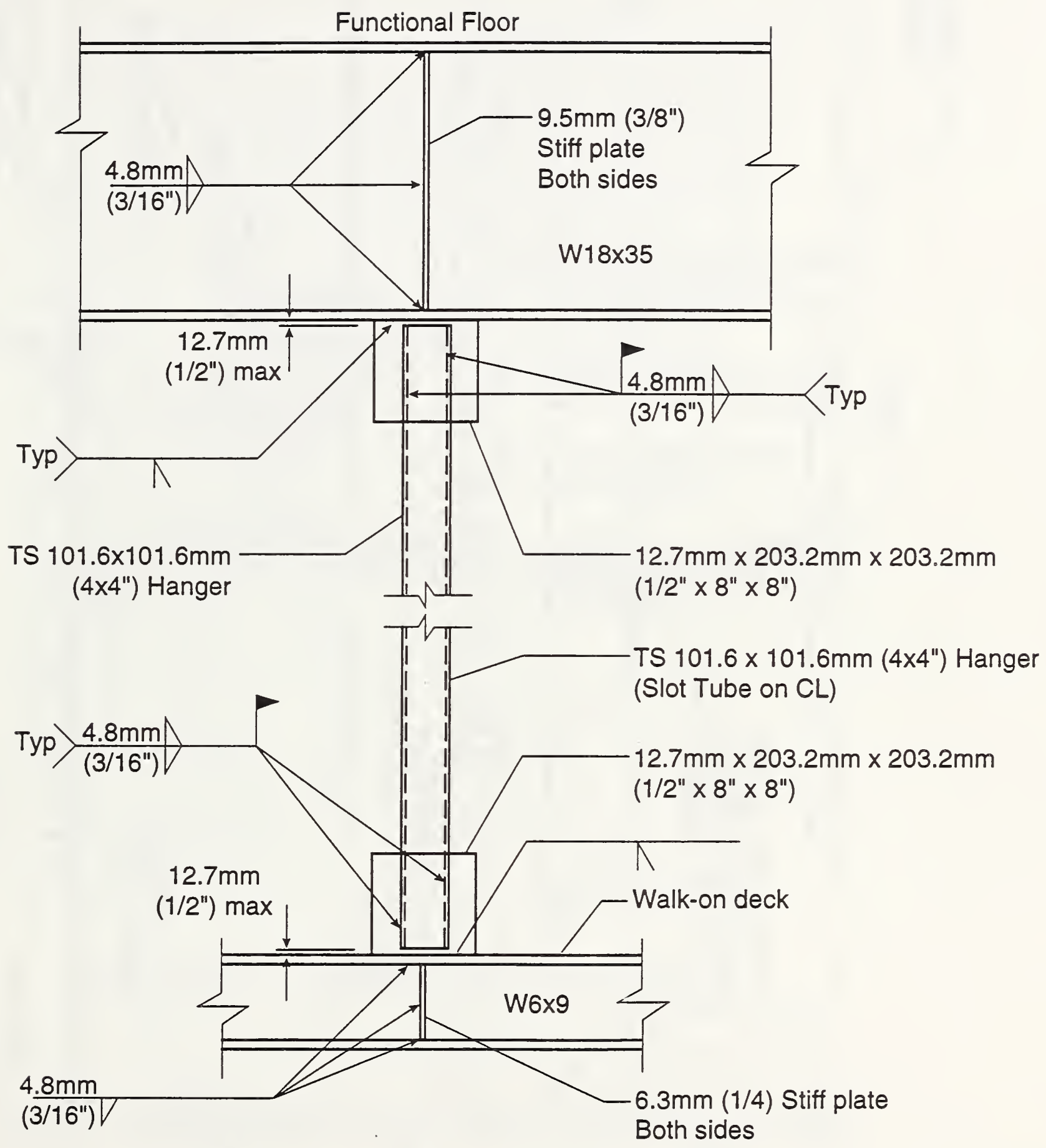

Figure 5. Fabrication details for construction of structural steel assembly 


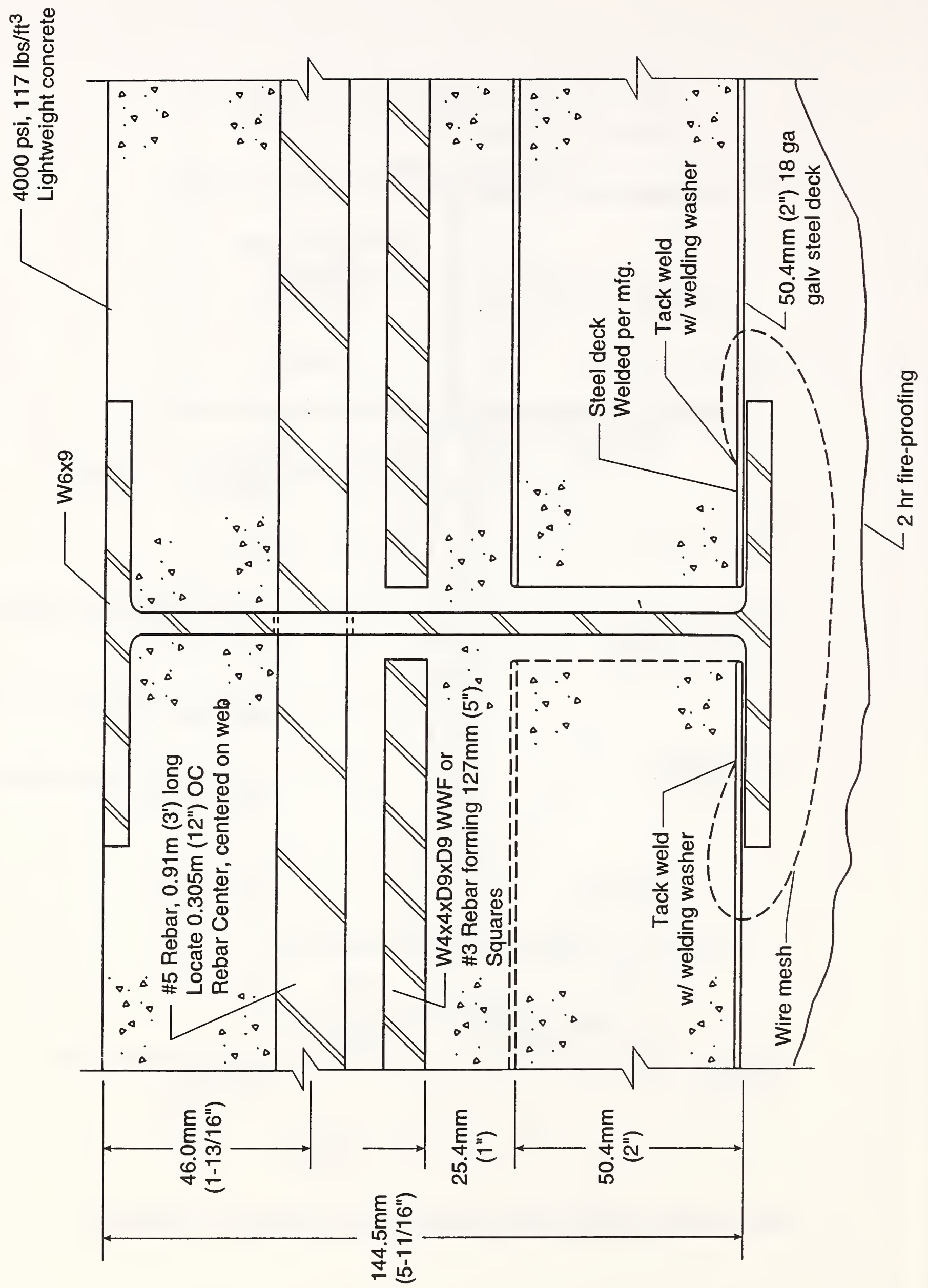




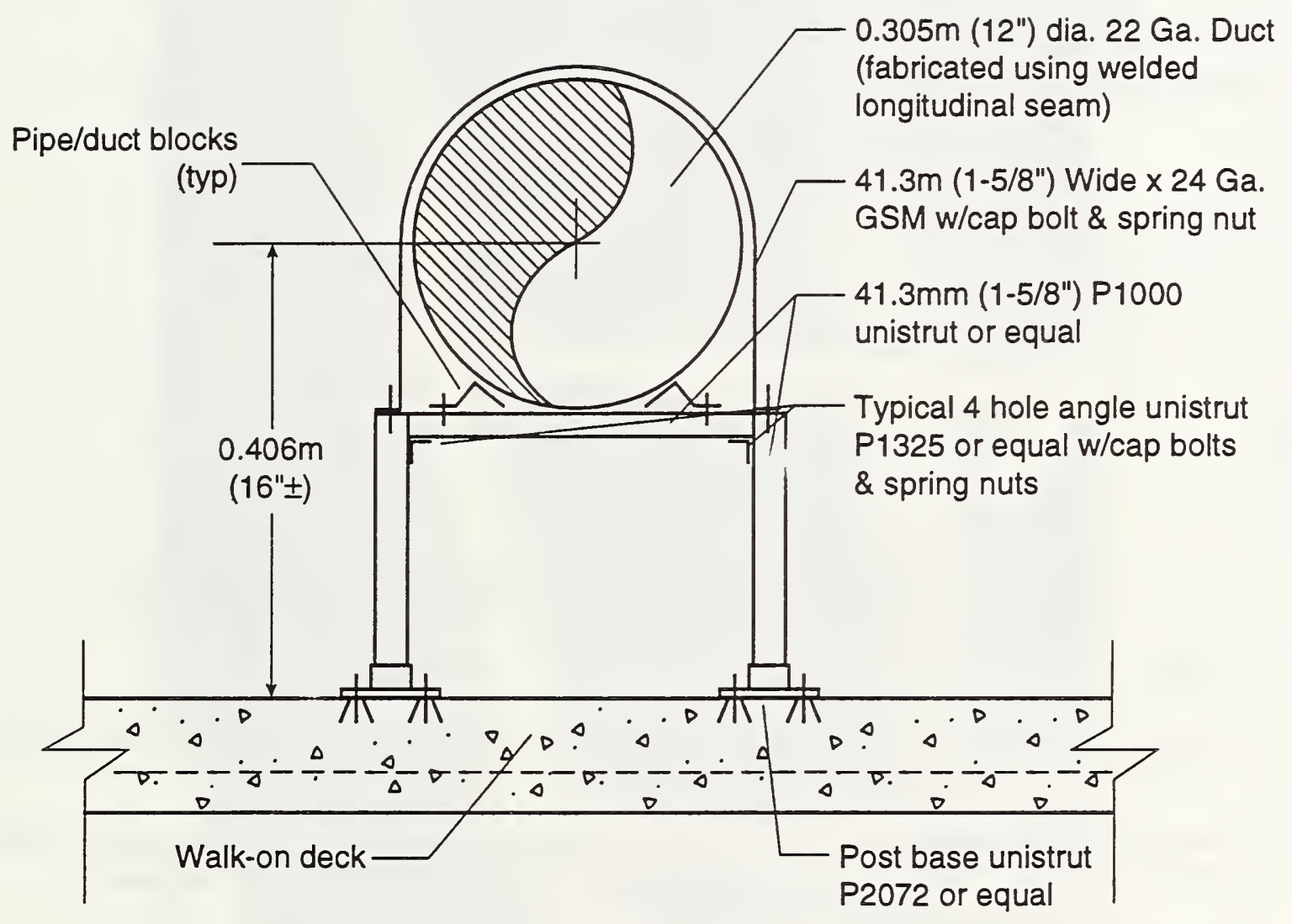

NOTE: Spacing of support not to exceed $2.946 \mathrm{~m}$ (9'8")

Figure 7. Horizontal supports for air conditioning ducts on walk-on deck 


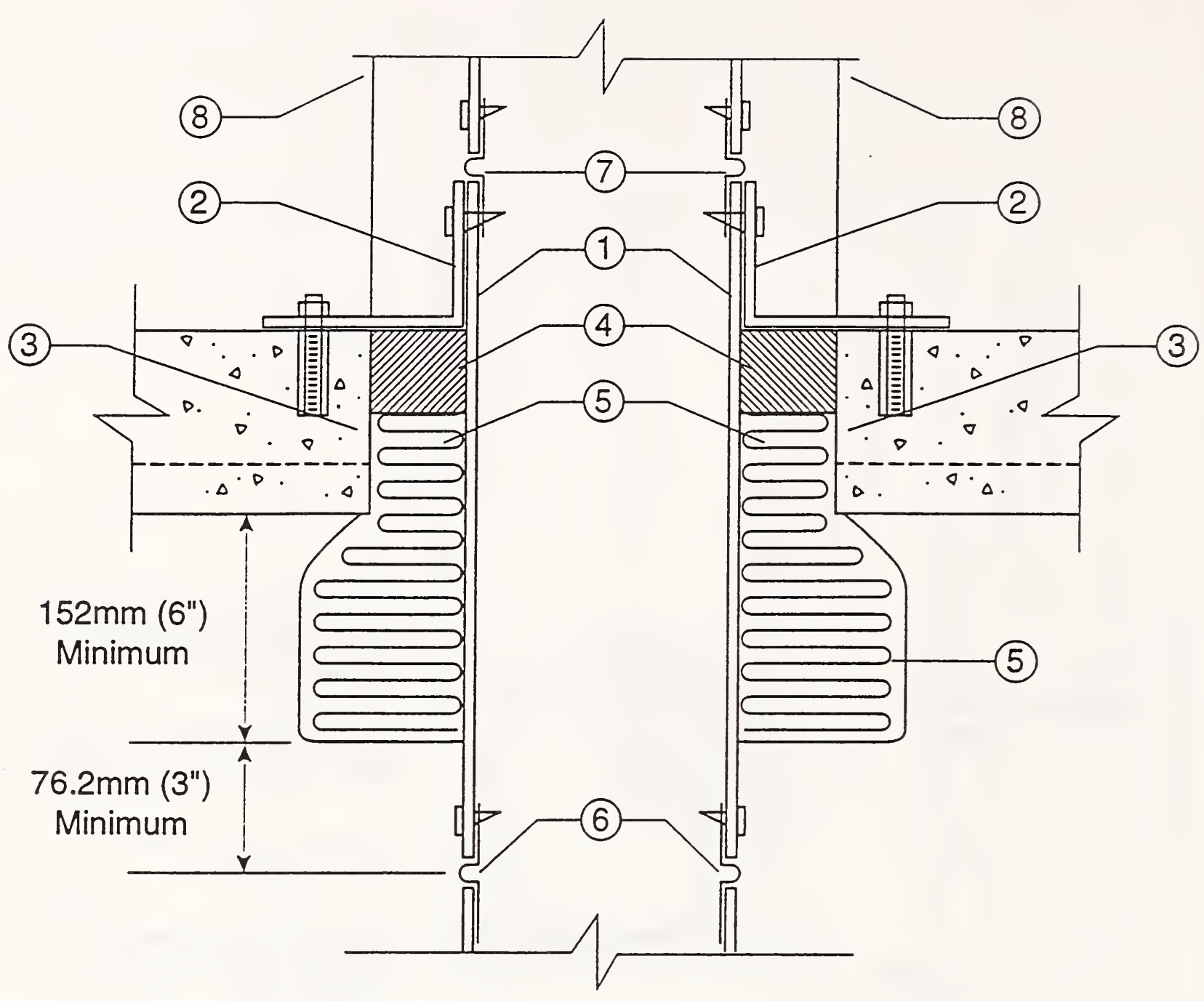

Figure 8. Details of firesafing of air conditionint duct penetrations

\section{DETAIL KEYED NOTES}

$0.305 \mathrm{~m}\left(12^{\prime \prime}\right)$ maximum round 22 gauge continuously welded longitudinal seam galvanized or stainless steel duct. Galvanized steel ducts used in NIST fire test.

Secure duct to deck with four $25.4 \mathrm{~mm}\left(1^{\prime \prime}\right)$ wide $76.2 \mathrm{~mm} \times 127 \mathrm{~mm}\left(3^{\prime \prime} \times 5^{\prime \prime}\right) \times 16$ ga. clip angles anchored to deck with $6.35 \mathrm{~mm}\left(1 / 4^{n}\right)$ expansion anchors located at least $76.2 \mathrm{~mm}\left(3^{n}\right)$ away from edge openings.

Poured in place opening in walk-on deck sized for $25.4 \mathrm{~mm}\left(1^{\prime \prime}\right)$ space all-around.

Intumescent fire/smoke compound install per conditions of listing for 2 hour rating.

(3M Fire Barrier CP-25-WB or Equal) A $50.2 \mathrm{~mm}$ (2 in) deep fill used in NIST fire test.

Pack annular space with $50.8 \mathrm{~mm}\left(2^{\prime \prime}\right)$ thick $0.641 \mathrm{~kg} \cdot \mathrm{m}^{3}\left(4 \mathrm{lbs} / \mathrm{ft}^{3}\right)$ density $0.036 \mathrm{~W} / \mathrm{mK}\left(0.25 \mathrm{BTU}-\mathrm{in}-/ \mathrm{Hr}^{\circ} \mathrm{F}\right) \mathrm{K}$ factor $1093^{\circ} \mathrm{C}\left(2000^{\circ} \mathrm{F}\right)$ melt point mineral wool safing and secure to duct with 16 gage tie wire where it extends below deck. Packed to within $50.8 \mathrm{~mm}$ ( $2 \mathrm{in}$ ) of the walk-on deck's top surface and extended a minimum of $76.2 \mathrm{~mm}$ ( 3 in) below the metal deck in NIST fire test.

Coupling with break-away joint connection to ductwork below.

7 Coupling connection to ductwork above.

8 Insulation only on the simulated supply duct. Simulated return duct had no insulation. 


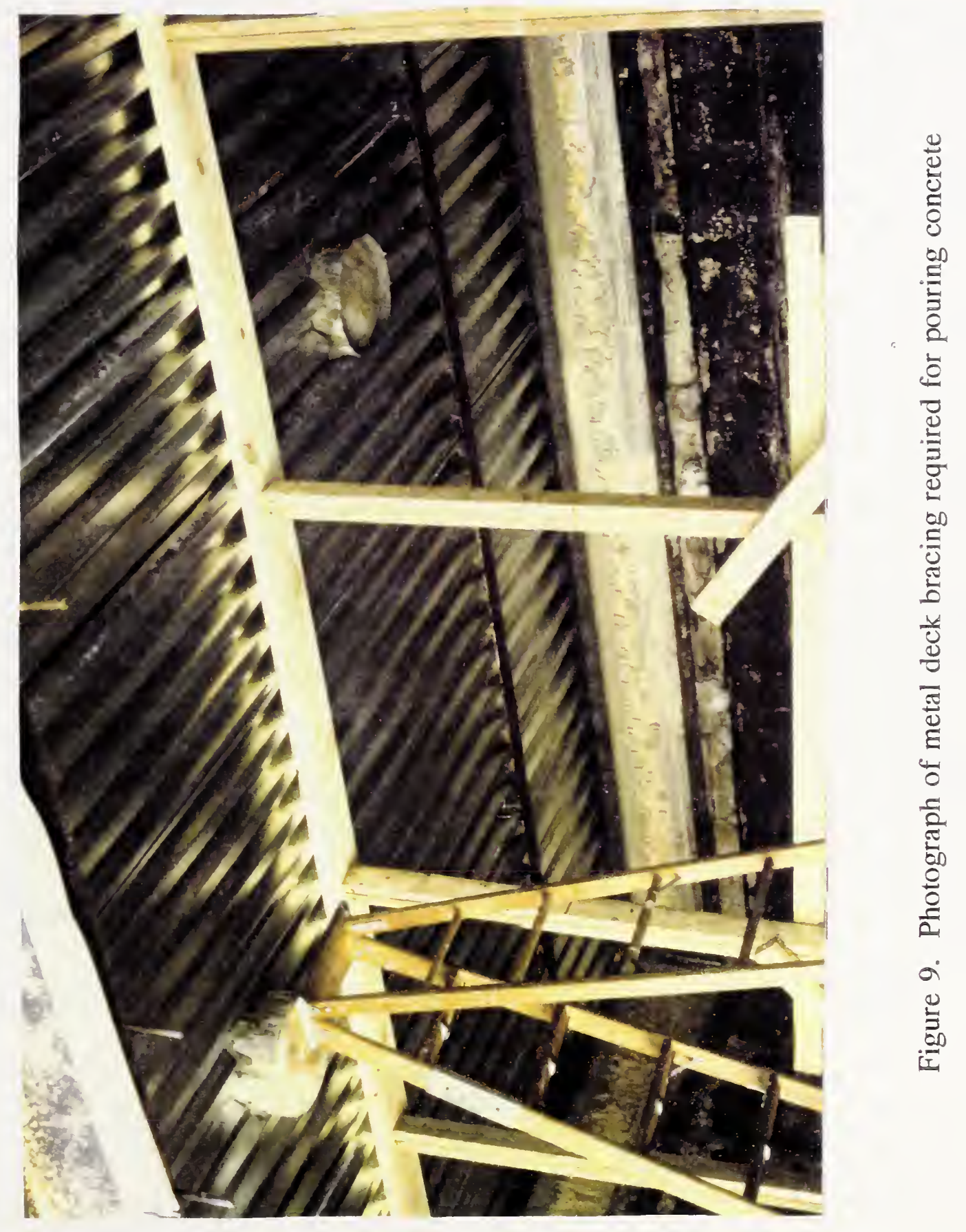





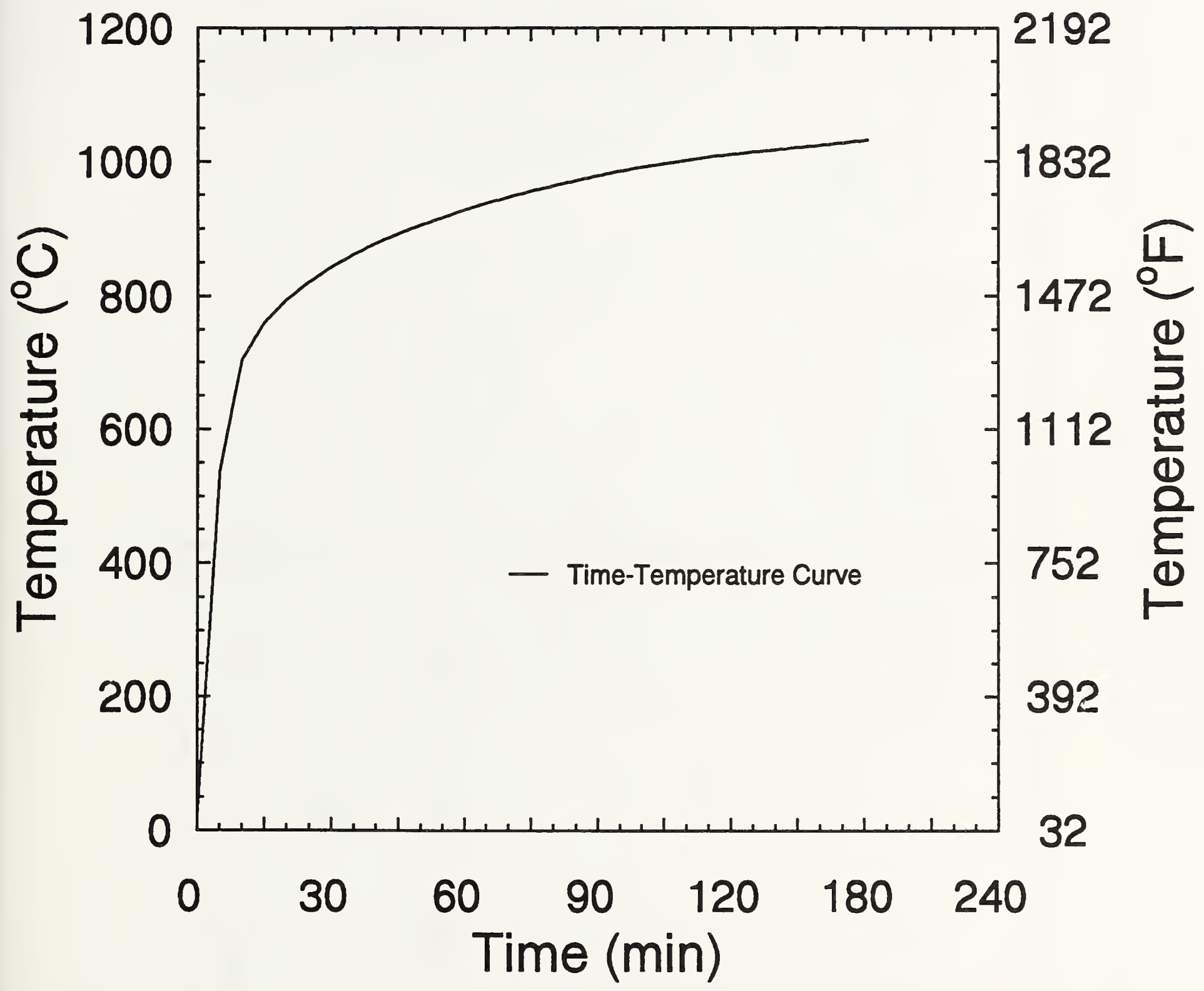

Figure 10. Standard NFPA 251 time-temperature curve for test furnace 



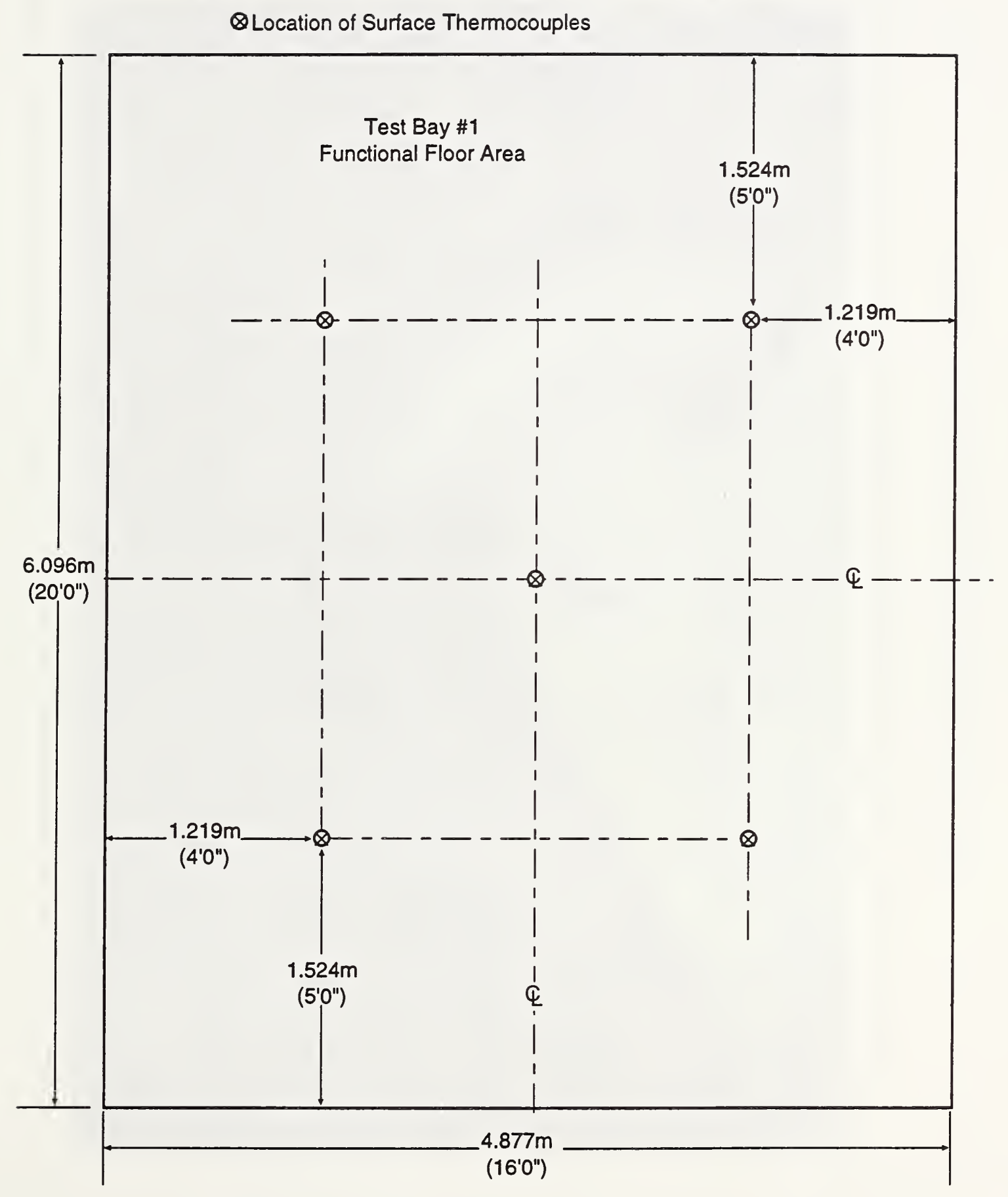

Figure 11. Standard thermocouple layout for temperature measurements on functional floor 


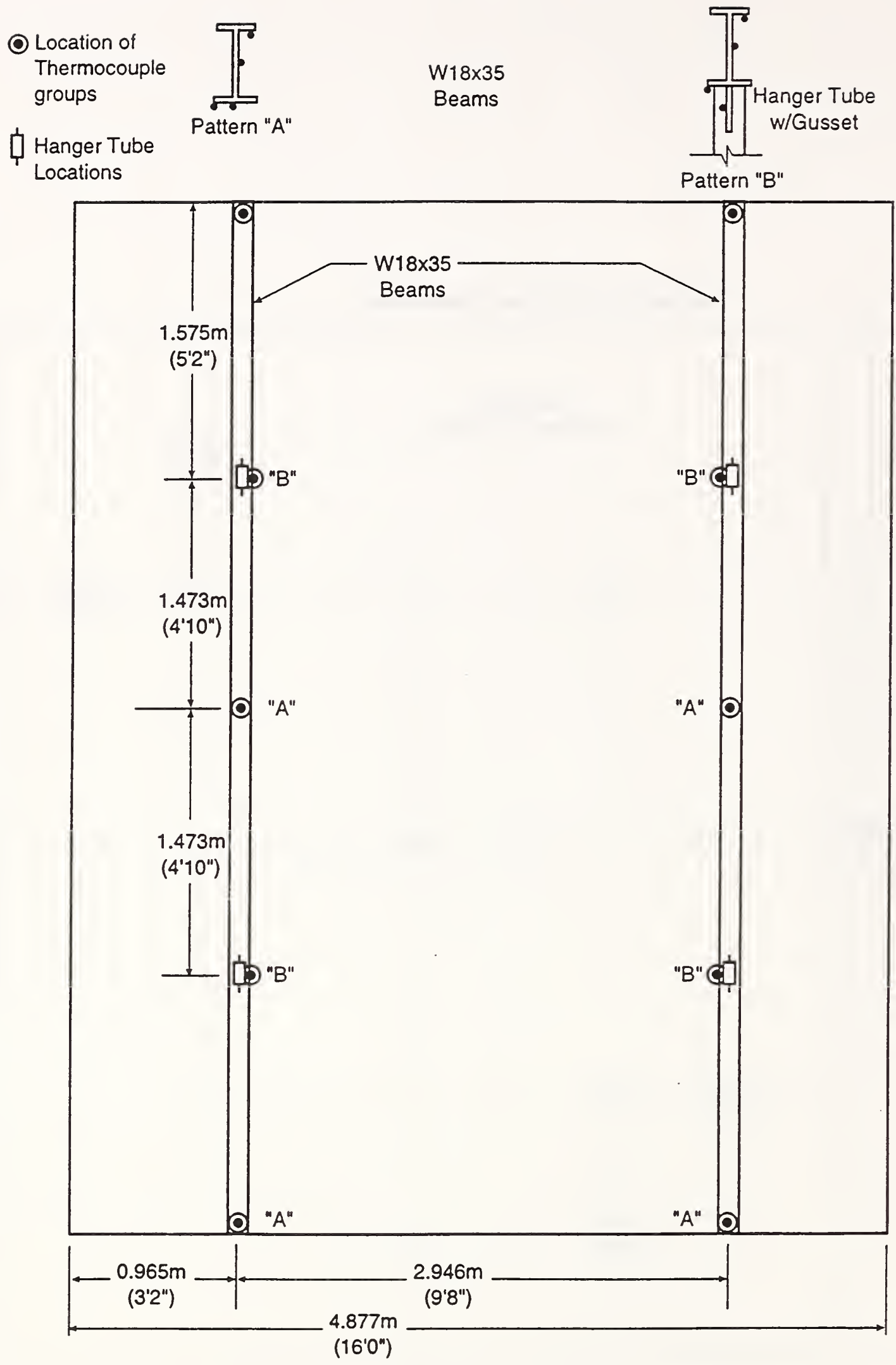

Figure 12. Thermocouple layout for $\mathrm{W} 18 \times 35$ beams 


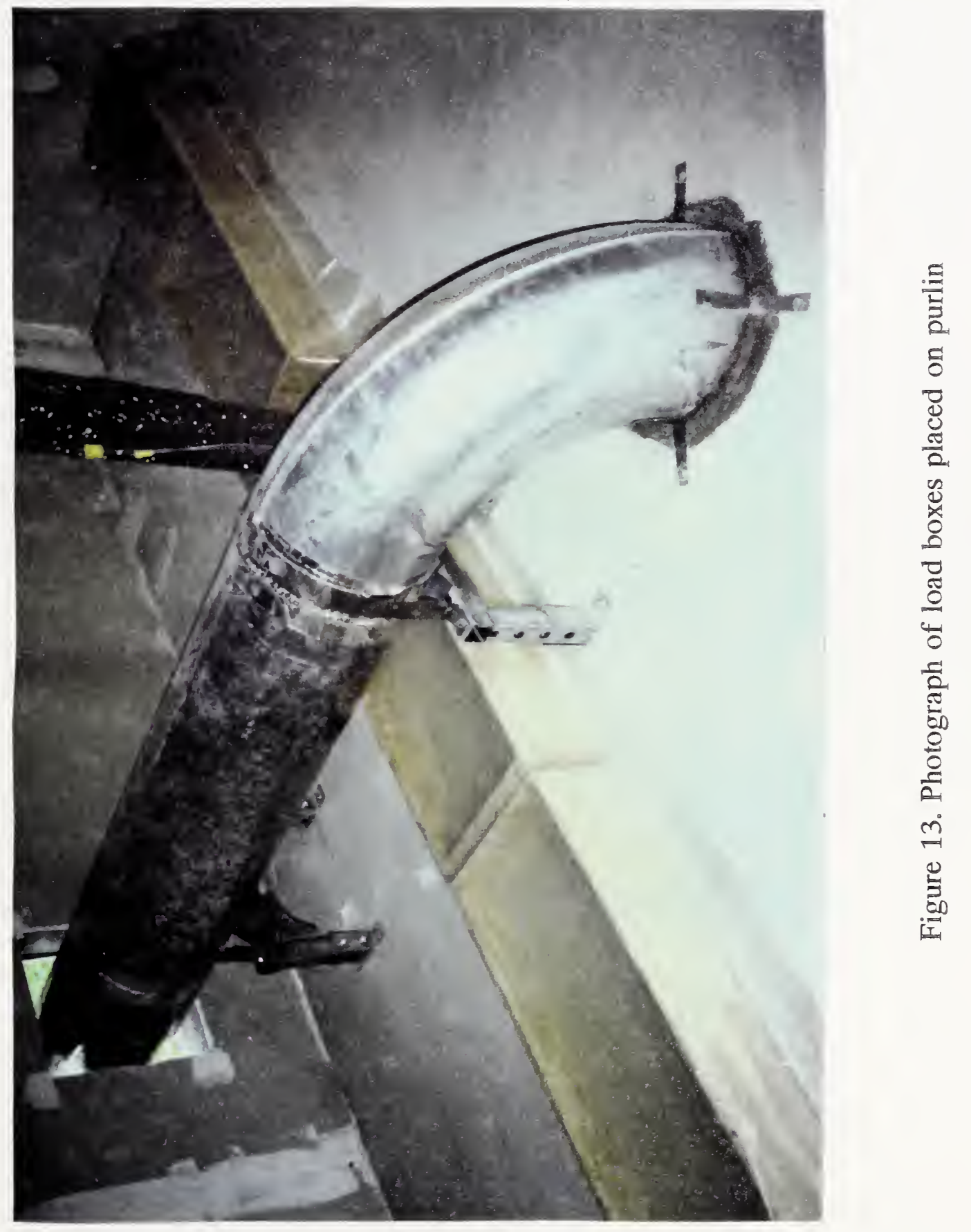





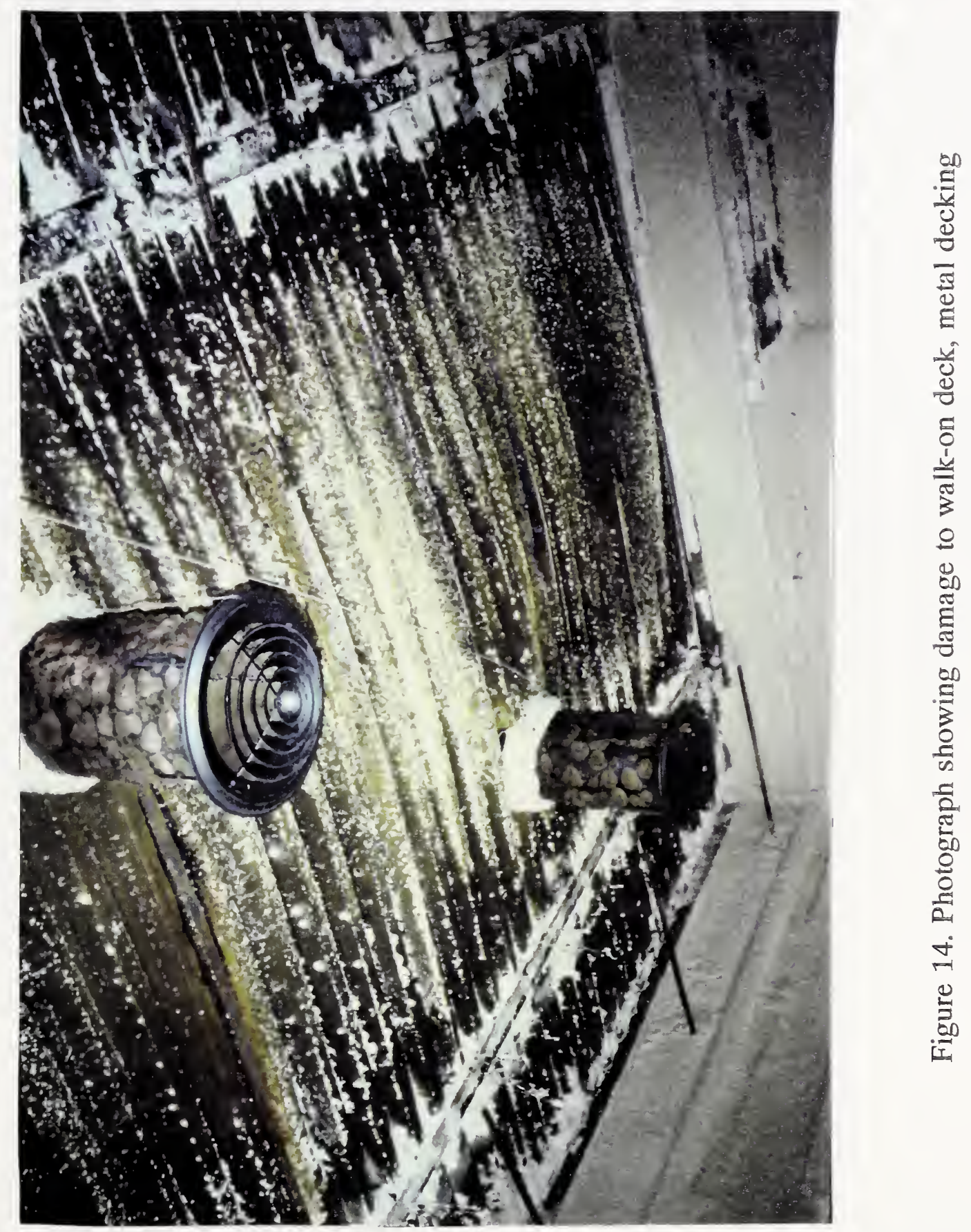





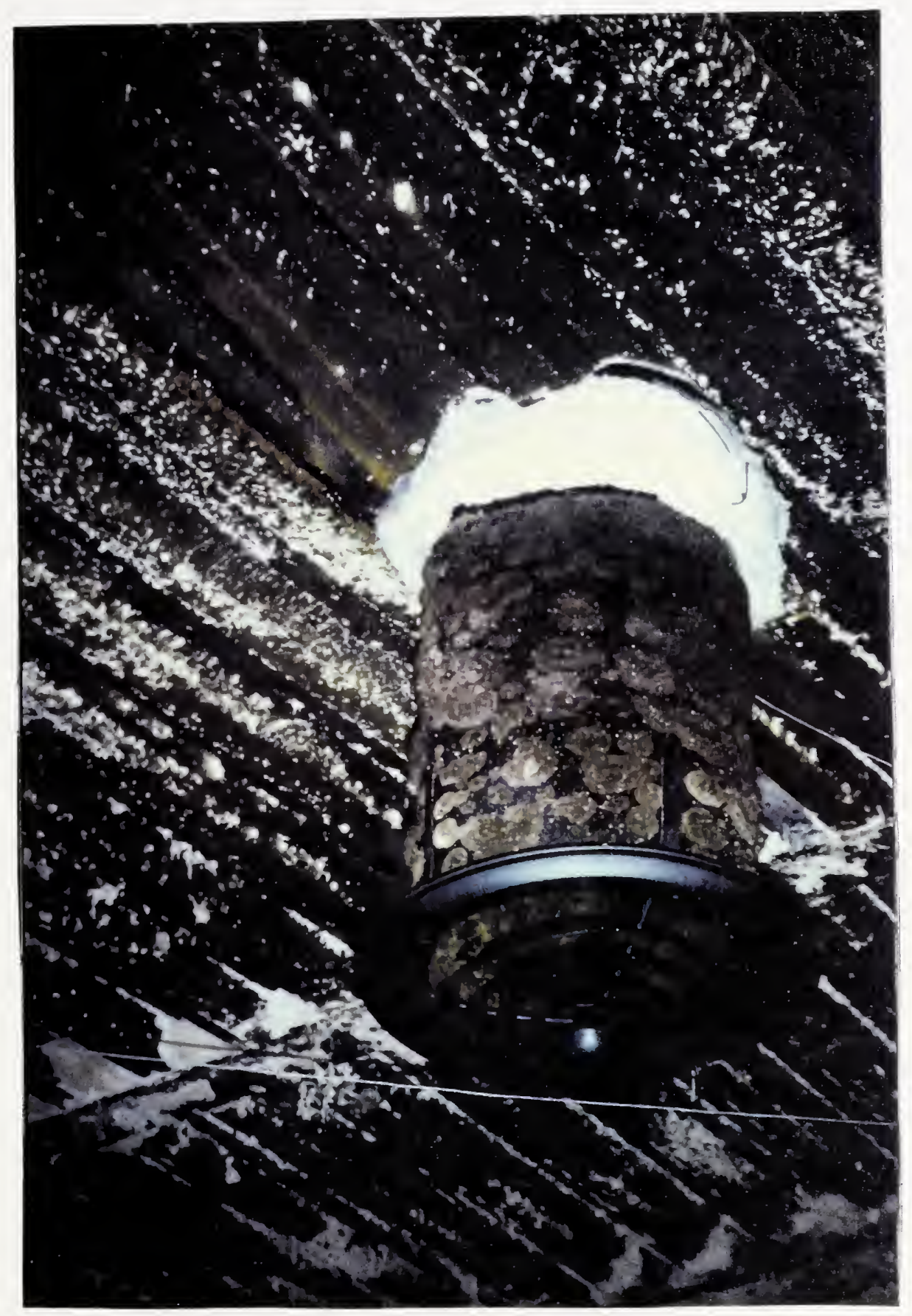

Figure 15. Photograph showing damage to air conditioning duct in fire compartment 



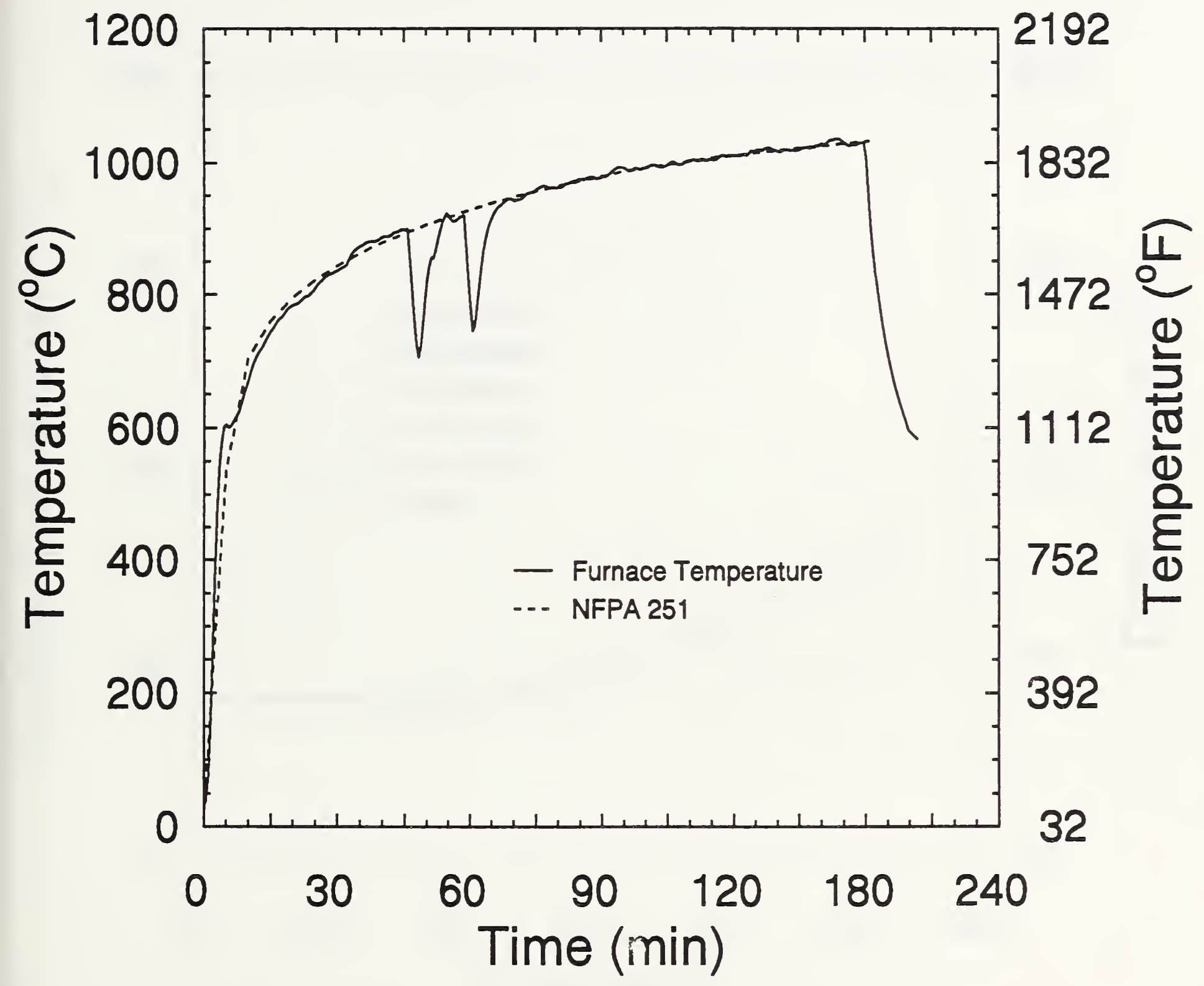

Figure 16. Standard NFPA 251 time-temperature curve vs. actual fire test curve 



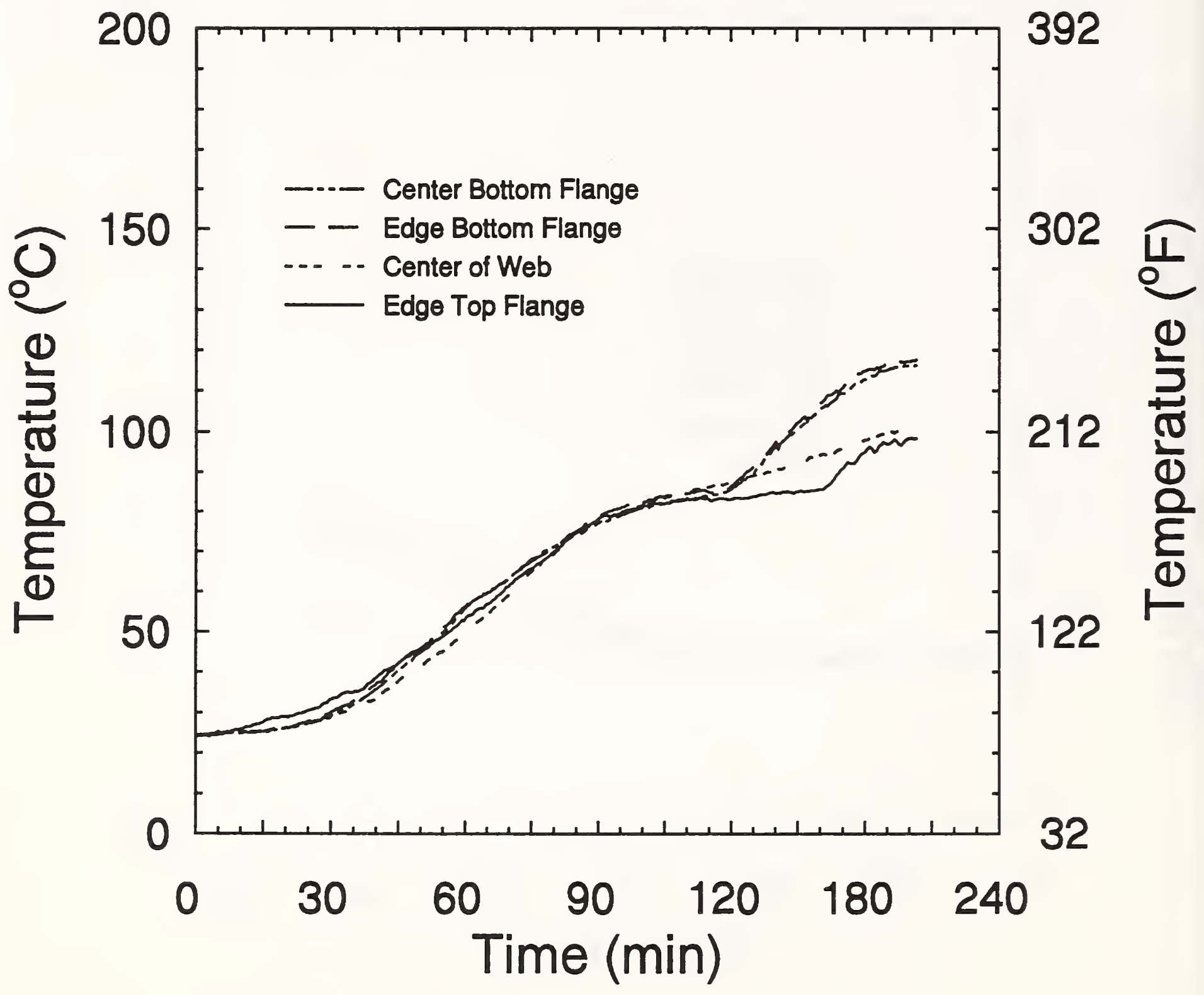

Figure 18. Temperatures on east W18x35 beam, north end 


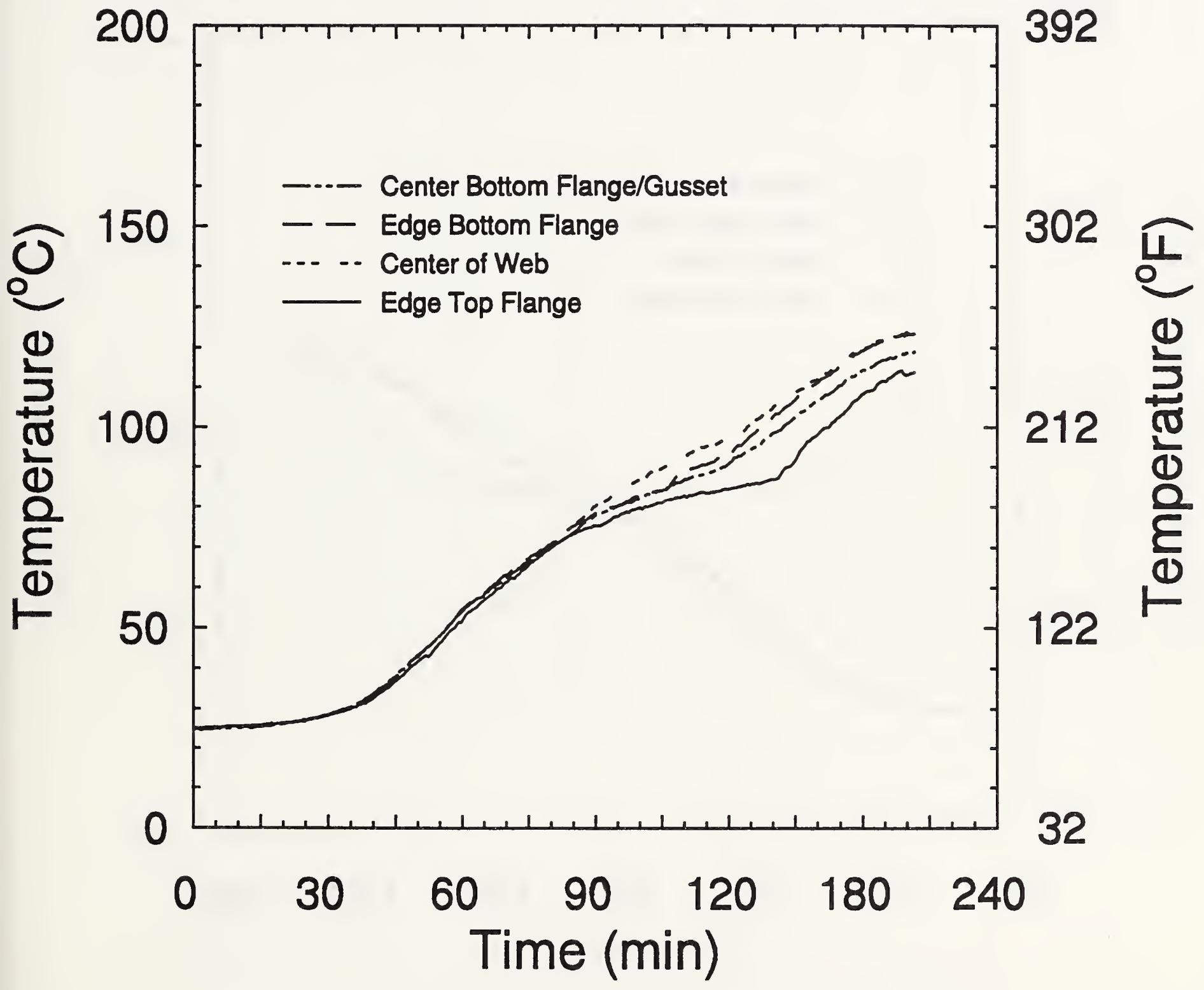

Figure 19. Temperatures on east $\mathrm{W} 18 \times 35$ beam, at north hanger 


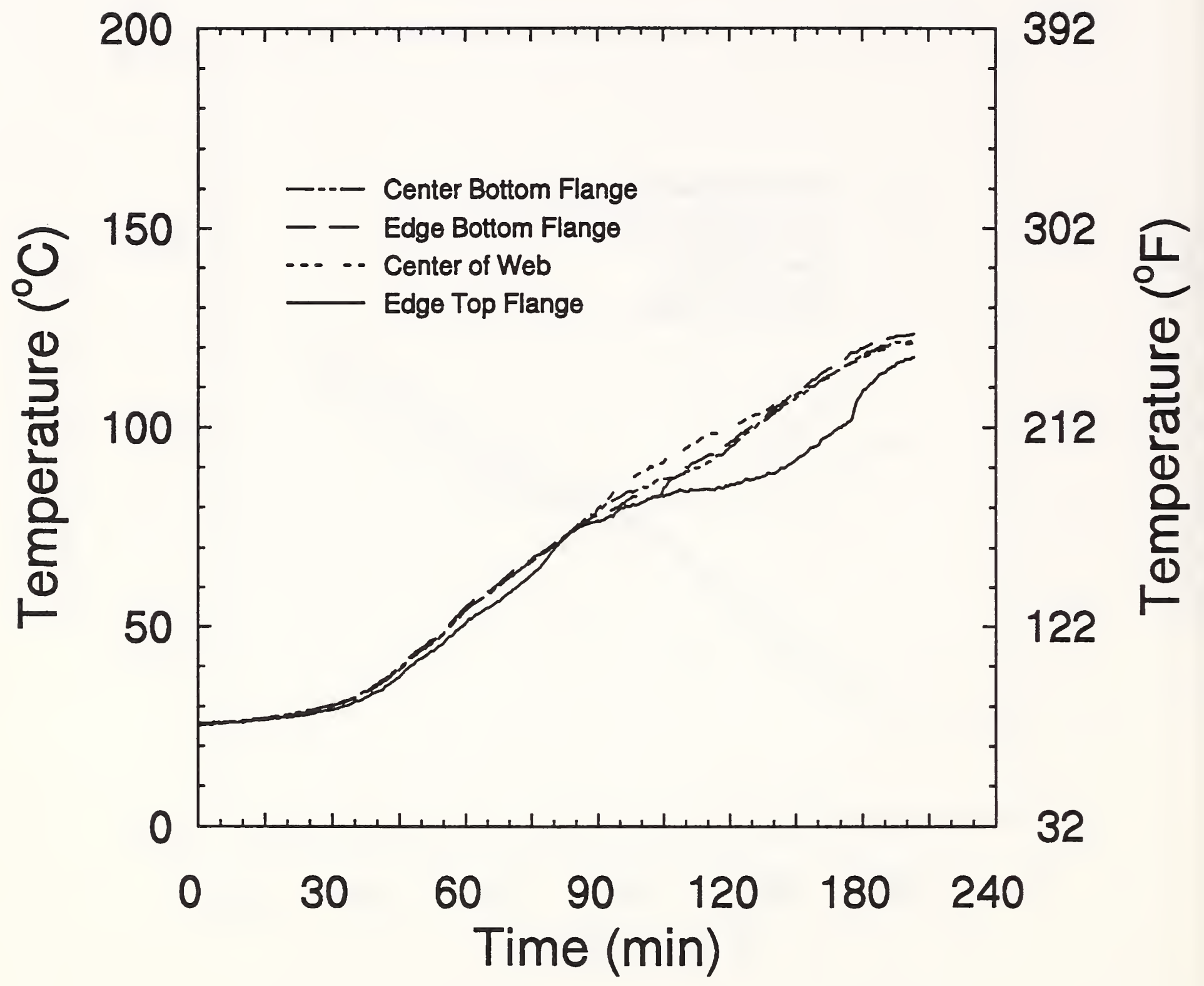

Figure 20. Temperatures on east $\mathrm{W} 18 \times 35$ beam, at center span 


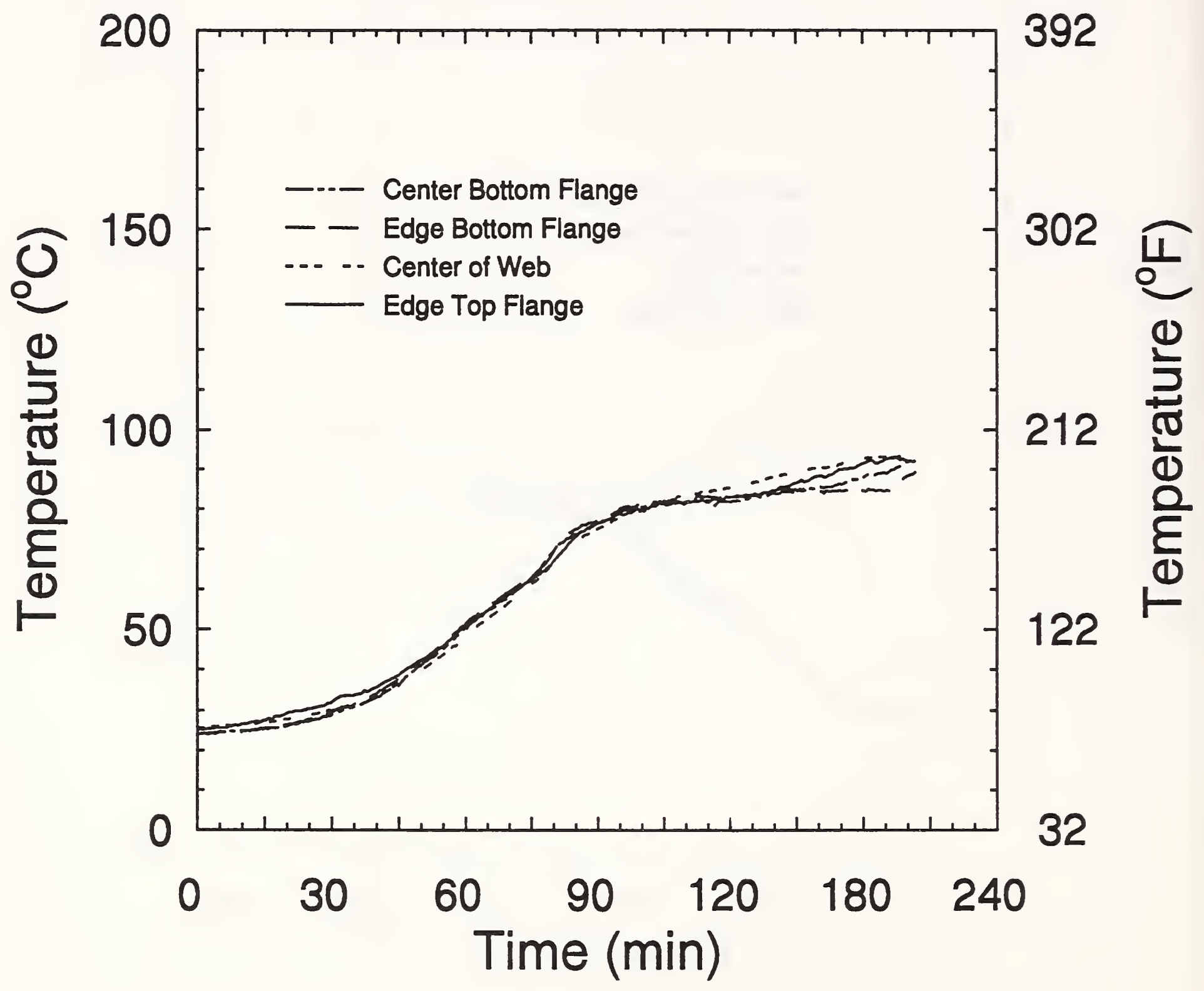

Figure 22. Temperatures on east $\mathrm{W} 18 \times 35$ beam, at south end 


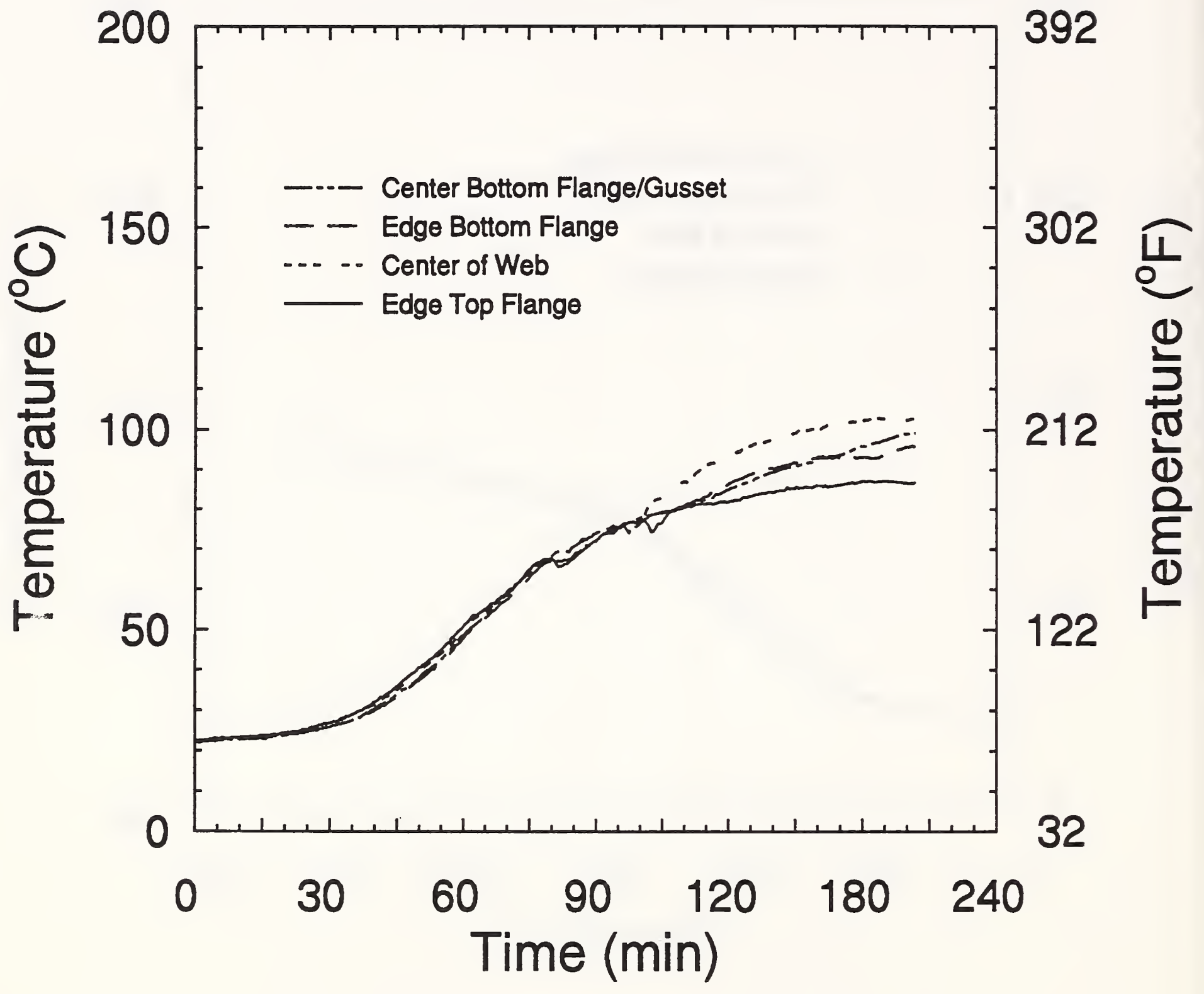

Figure 24. Temperatures on west $\mathrm{W} 18 \times 35$ beam, at north hanger 


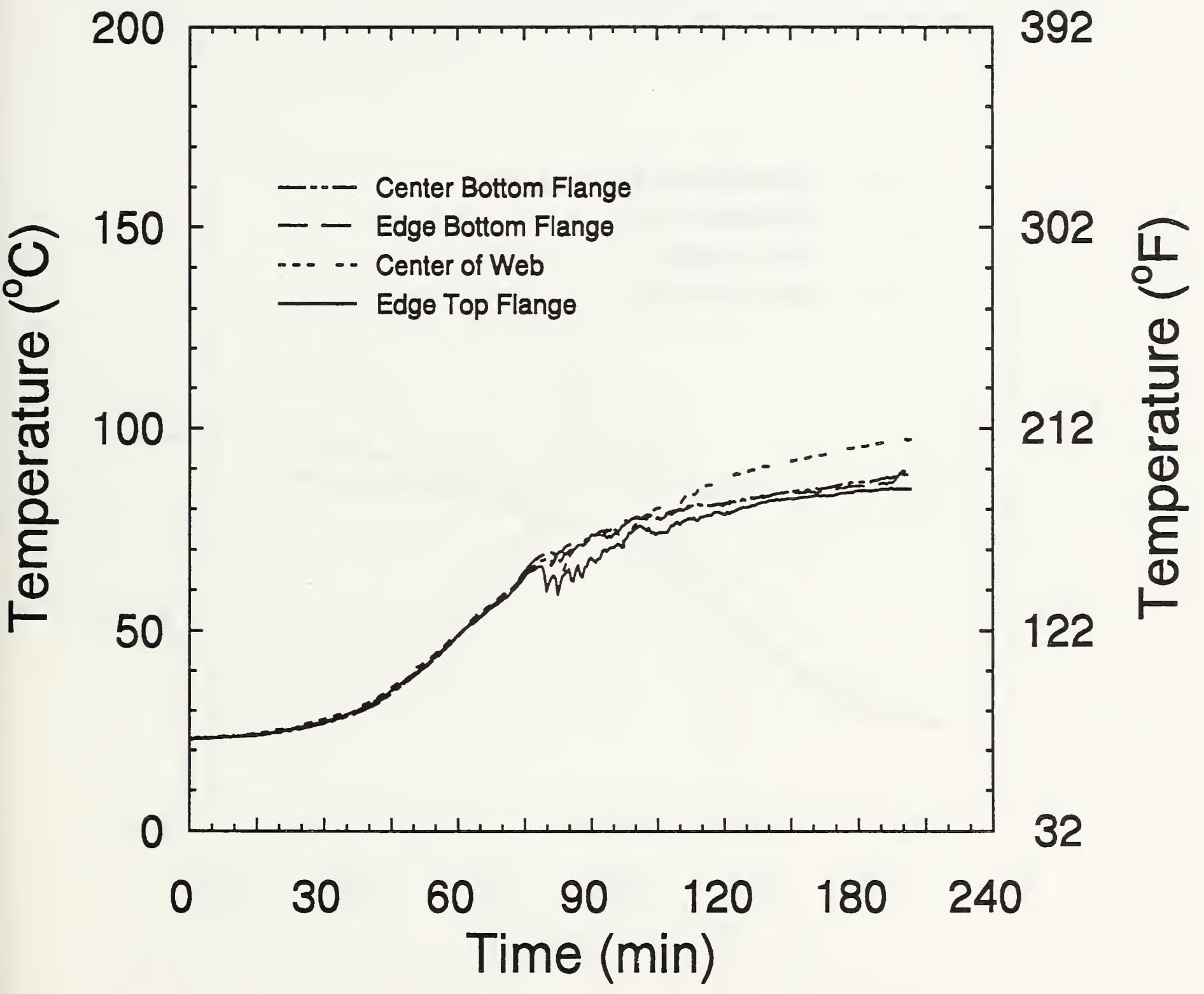

Figure 25 . Temperatures on west W18x35 beam, at center span 


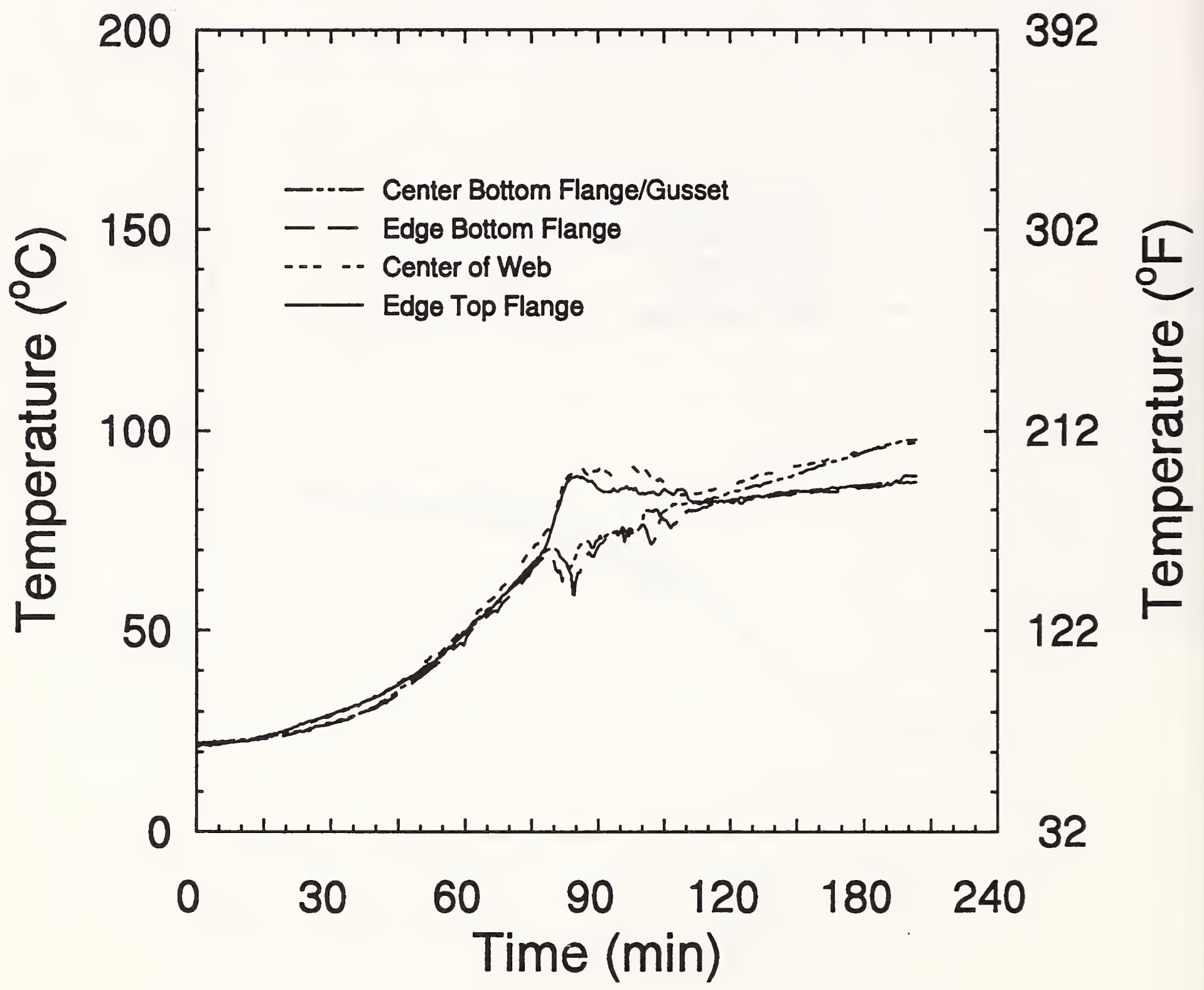

Figure 26. Temperatures on west $\mathrm{W} 18 \times 35$ beam, at south hanger 


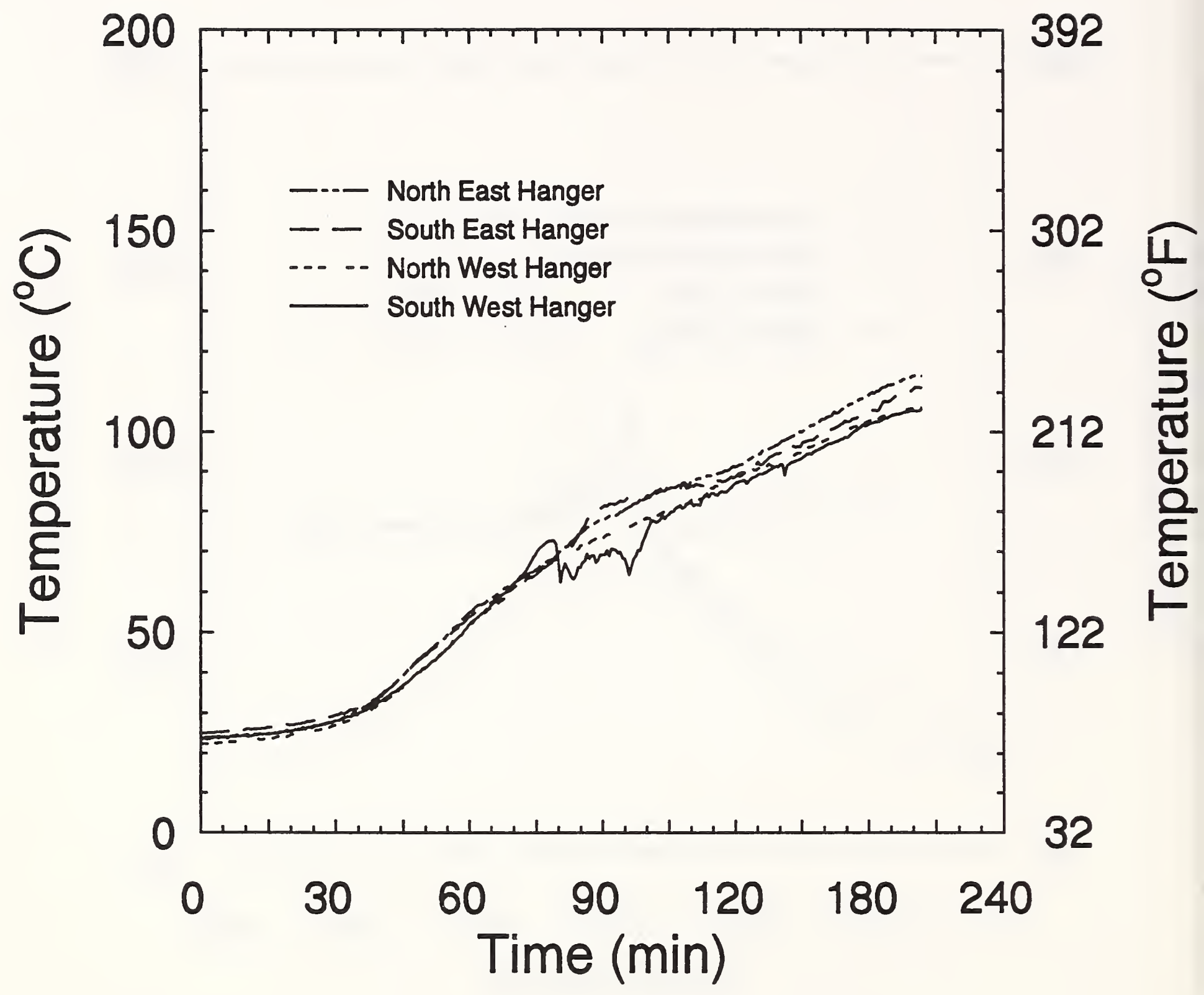

Figure 28. Mid-height temperatures on deck hanger tubes 


\section{APPENDIX A}

\section{A1.0 Uncertainty Analysis}

The following assesses uncertainties associated with instruments which were used to determine the fire endurance period of the interstitial space designed by DoD. Test instruments used in this analysis were installed according to NFPA 251. This analysis follows that prepared by Steckler [1]. Since only one test was conducted at only one laboratory, no statement can be made about repeatability, within-laboratory variability, or reproducibility, between-laboratory variability. In addition, no data exist which would allow for a repeatability evaluation for the NIST steel structure fire endurance furnace.

There are two critical measurements which effect the conduct of the test. These are time and temperature.

\section{Time}

With this test, time was maintained with a computer-based clock having an accuracy better than one second over a test period from one to four hours. The timing uncertainty which has the greatest influence on the data is that associated with the ability of the computer controlled data acquisition system to scan 97 data channels in less than four seconds on a 10 second interval. Since the computer clock is read at the beginning of each scan, a particular temperature measurement is made and recorded up to four seconds after the scan time was recorded. As a result, the maximum combined uncertainty in the time measurement, $\mathrm{C} 1$, due to clock uncertainty and uncertainty of the scanning process is judged to be no more than $+5 /-1$ seconds.

\section{Temperature}

Uncertainties related to the measurements of the unexposed surface temperatures and the furnace temperatures also contribute to the total uncertainty of the fire endurance period measured by the test.

Unexposed surface temperatures - Sources of error for the unexposed surface temperatures were considered over the range of $75{ }^{\circ} \mathrm{C}$ to $166^{\circ} \mathrm{C}$. The following uncertainties were considered: inherent accuracy of the thermocouple materials, $\pm 2.2{ }^{\circ} \mathrm{C}[2]$; accuracy of the voltage-to-temperature conversion polynomial, $+0.3 /-0.64{ }^{\circ} \mathrm{C}[3]$; and accuracy of the digital voltmeter (DVM) used to measure the thermocouple voltages, $+0.68 /-0.64{ }^{\circ} \mathrm{C}$.

Note: The accuracy of the DVM was determined by a precision voltage source of known accuracy, and the temperature uncertainty for the DVM is the ratio of the voltage uncertainty to the thermoelectric power $\left(\mathrm{mV} /{ }^{\circ} \mathrm{C}\right)$ of the thermocouple materials. 
By summing the above uncertainties, a maximum uncertainty of $+3.2 /-3.0$ was obtained. These values were conservatively simplified to $\pm 3.2^{\circ} \mathrm{C}$. By dividing this uncertainty by the average rate of temperature change on the unexposed surface at the indicated fire endurance time, the attendant uncertainty of the fire endurance period, $\mathrm{C} 2$, is obtained.

Furnace temperatures - The source of error for the furnace temperatures were considered over the range of $20^{\circ} \mathrm{C}$ to $1100{ }^{\circ} \mathrm{C}$. The following uncertainties were considered: inherent accuracy of the thermocouple materials, $\pm 2.2^{\circ} \mathrm{C}$ or $0.75 \%$ (C scale) [2], which ever is greater; accuracy of the voltage-to-temperature conversion polynomial $\pm 0.7^{\circ} \mathrm{C}[3]$; and accuracy of the DVM used to measure the thermocouple voltages, expressed as third-order polynomials relating temperature uncertainty to temperature.

These uncertainties were summed with the experimental temperature-time curve to obtain maximum and minimum furnace temperature-time curves for the test period of 2 hours. These bounding curves were integrated with respect to time and the results processed per NFPA 251, section A-3-1.4 [4] to determine corrections to the indicated fire-endurance period to account for variations in furnace temperature. These corrections are identified below as C3.

\section{A2.0 Combined Uncertainty}

Total maximum uncertainty for this experiment is calculated as the sum of $\mathrm{C} 1, \mathrm{C} 2$, and $\mathrm{C} 3$ and is reported below.

\section{Test Uncertainty}

C1: Uncertainty resulting from time measurement,

Unexposed surface temperature heating rate, at $2 \mathrm{hr} \mathrm{dT} / \mathrm{dt}$ :

C2: Uncertainty of unexposed surface temperature measurement, $\pm 3.2{ }^{\circ} \mathrm{C} /(\mathrm{dT} / \mathrm{dt})$,

C3: Uncertainty of furnace temperature measurement [ref. 1],

Total maximum uncertainty $(\mathrm{TMU})=\mathrm{C} 1+\mathrm{C} 2+\mathrm{C} 3$ : $+5,-1(s)$

$0.004\left({ }^{\circ} \mathrm{C} / \mathrm{s}\right)$

\pm 800 (s)

$+30,-27(s)$

$+835,-828(s)$ 
The total maximum uncertainty defines the time required in seconds to be assured that one can detect a temperature change of $\pm 3.2{ }^{\circ} \mathrm{C}$ at a fire endurance time of 2 hours.

Calculated fire endurance (CFE) period at test shutdown, 9600 (s) 2 hours 30 minutes, using integrations and calculations 2:40 (hr:min) specified in NFPA 251, section A-3-1.4

Percent maximum uncertainty for this test:

$((\mathrm{TMU}) /(\mathrm{CFE})) \times 100$

\section{References}

[1] Steckler, Kenneth, D., Report of Test FR 3994 on Pilot-Scale Fire-Endurance Tests of Fire Barrier Mats, Blankets, and Panels, National Institute of Standards and Technology, Gaithersburg, MD, 1994.

[2] Manual On The Use of Thermocouples in Temperature Measurement, ASTM Special Technical Publication 470, American Society for Testing and Materials, Philadelphia, PA 1970, p. 151.

[3] Omega Complete Temperature Measurement Handbook and Encyclopedia, Vol. 26 Omega Engineering Inc., Stamford, Ct, 1988, p. T-12.

[4] NFPA 251 Fire Tests of Building Construction and Materials 1990 Edition, National Fire Protection Association, Quincy, MA, 1990. 


\section{APPENDIX B}

\section{B1.0 Additional Instrumentation}

In order to gain a more complete understanding of the interstitial space construction assembly's performance, additional instrumentation beyond that required by NFPA 251 was added. A total of 39 additional thermocouples were located throughout the construction assembly. Also, deflection gauges were used to measure structural movement in the walk-on deck.

\section{B1.1 Top Surface of the Walk-on Deck}

Five $0.5 \mathrm{~mm}, 24$ gage, bare bead, type $\mathrm{K}$ thermocouples were positioned on the top surface of the walk-on deck. See figure B1. These measured temperature change on the unexposed surface to provide information on the deck's performance while being exposed to the standard furnace heating environment. These thermocouples were covered with standard $9 \mathrm{~mm}$ (0.375 in) refractory pads as done on the top surface of the functional floor.

\section{B1.2 W6x9 Steel Purlins Supporting the Walk-on Deck}

Two groups of four thermocouples were attached to each of the steel purlins. Each group was located near one of the four steel hanger tubes, as shown in figure B1. These were all stainless steel sheathed, $3 \mathrm{~mm}(0.125 \mathrm{in})$ diameter, type $\mathrm{K}$ thermocouples. They were secured to the purlins using the same technique described in section 6.1.2 of the main report.

\section{B1.3 Steel Deck Supporting the Walk-on Deck}

Three groups of stainless steel sheathed, $3 \mathrm{~mm}(0.125 \mathrm{in})$ diameter, type $\mathrm{K}$ thermocouples were positioned on the galvanized steel decking which supported the walk-on deck concrete. Thermocouple patterns and locations are shown in figure B1. Three of the four thermocouples were attached to the metal deck and one was located at mid-depth in the concrete. The thermocouple group located at the walk-on deck's center had an additional feature, a top surface thermocouple positioned above the group. This configuration allowed for the determination of a temperature profile through the finished walk-on deck.

\section{B1.4 Thermocouples on Air Conditioning Ducts}

One $0.5 \mathrm{~mm}, 24$ gage, bare bead, type $\mathrm{K}$ thermocouple was attached to each of the two air conditioning ducts. These were taped to the surface of the ducts with high temperature glass fiber tape. Thermocouple locations are shown in figure 3 of the main report. The longest duct simulated an air conditioning supply duct. On this duct, the thermocouple was put into place 
before the thermal insulation was attached. The thermocouple on the simulated return duct had no thermal insulation covering it.

\section{B1.5 Deflection Instrumentation}

Two linear deflection gauges were used to measure movement of the walk-on deck's W6x9 steel purlins, as shown in figure B1. The measurement transducers were located outside of the interstitial space. Mechanical slide wires from these gauges passed through holes in the interstitial space walls and were attached to weights that sat on the top of the purlin's load bearing sand boxes. Figure B2 shows a picture of the slide wire and weight installation.

\section{B2.0 Test Results}

\section{B2.1 Walk-on Deck Results}

Three thermocouples were attached to the metal decking supporting the lightweight concrete, and one thermocouple was positioned at mid-depth in the concrete as shown in figure B1. This figure also gives locations on the deck for each thermocouple group. In addition, the thermocouple group located in the center of the walk-on deck had a fifth thermocouple located on the surface. Data plots for these thermocouple groups are shown in figures B3, B4 and B5. These data plots clearly show, as the thermocouples become more distant from the fire exposed side of the assembly and embedded in the concrete, temperatures and fluctuations decrease. All three thermocouple groups (north, center and south) have similar patterns and temperature histories. The center group shown in figure B4 exhibits a crossover in measurements between the side of flute and top of flute measurements. This resulted from the thermocouples being dislodged when the metal decking separated from the concrete, early in the test. In addition, figure B4 gives measurements for the surface thermocouple. As can be seen, temperature on the unexposed side of the walk-on deck did not exceed $100^{\circ} \mathrm{C}\left(212^{\circ} \mathrm{F}\right)$ for this thermocouple.

Four other surface thermocouples were located on the walk-on deck. These were located as shown in figure B1. Test results are presented in figure B6. These data show that surface temperature generally climbed at a steady rate between 30 minutes and about 1 hour 15 minutes. Temperatures then tended to level out at $100{ }^{\circ} \mathrm{C}\left(212^{\circ} \mathrm{F}\right)$ until about 2 hours 15 minutes. The north west quadrant thermocouple suddenly began to rise. By the time of test termination, the temperature in this quadrant had risen to more than $121^{\circ} \mathrm{C}\left(250^{\circ} \mathrm{F}\right)$. Temperature increases for three of the five thermocouples on the walk-on deck after 2 hours are less than the $121{ }^{\circ} \mathrm{C}$ $\left(250^{\circ} \mathrm{F}\right)$ temperature criteria required for the functional floor acceptance.

Purlin temperatures are shown in figures B7, B8, B9 and B10. Of these measurements, the most significant is related to a two hour rating for the fire proofing. The purlin performance is shown in figure B8. A rapid temperature rise is noted in the south east quadrant starting at 90 minutes into the test. This continued until a single point temperature measurement of $704^{\circ} \mathrm{C}\left(1300^{\circ} \mathrm{F}\right)$ was recorded at 1 hours 54 minutes into the test. Under standard NFPA 251 test criteria for a closely coupled flooring assembly, this would have been a failure. Under the acceptance criteria 
used with this and the earlier Veterans Administration (DVA) test assemblies, this temperature measurement has no influence on acceptance. With this interstitial space design, the walk-on deck, which is suspended from above, is successfully protecting the larger steel beams supporting the upper functional floor. Therefore, the high purlin temperature did not result in a failure of the system since the primary objective is protection of the steel within the interstitial space and the functional floor above. A second thermocouple also reached this critical temperature shortly after 2 hours 10 minutes into the test. Critical purlin temperatures were also reached at the north east quadrant location just after two hours into the test, as shown in figure B7.

Joints of the metal decking which supported the lightweight structural concrete opened up during the fire exposure. Test observations presented in section 7.2 indicate that the overlapped flutes which formed the decking joints began to open as early as three minutes into the test. These joints opened to at least $100 \mathrm{~mm}(4 \mathrm{in})$ and sagged in the center toward the furnace floor. See the photograph in figure 14 of the main report. Despite these openings, the assembly met the requirements for a minimum two hour rating.

\section{B2.2 Ducts and Duct Penetrations}

The two air conditioning ducts maintained their integrity throughout the test. As expected, the insulated supply duct exhibited higher temperatures than the uninsulated return duct, as shown in figure B11. By the end of the test, the insulated duct's surface temperature, as measured in the interstitial space, exceeded $480^{\circ} \mathrm{C}\left(896^{\circ} \mathrm{F}\right)$. The uninsulated duct had a maximum temperature of $252{ }^{\circ} \mathrm{C}\left(486{ }^{\circ} \mathrm{F}\right)$. This lower temperature is attributed to the duct's greater heat loss rate.

Duct sections which extended into the fire environment maintained their integrity throughout the test period. However, large blisters were noted covering the duct's surfaces as the test ended. See the photograph in figure 15 of the main report.

The firesafing and smoke sealer remained in place throughout the fire exposure period. This prevented the transmission of smoke and hot gases through the duct openings into the interstitial space. Smoke noted in the test observations generally came from around the walk-on deck's perimeter, and some was generated by smoldering paper on the gypsum board walls enclosing the interstitial space.

\section{B2.3 Deflection Measurements}

Deflection measurements taken at center span for the two purlins showed no deflection for these structural members. This is significantly different from that experienced with the purlins tested for the Veteran's Administration during 1983. No data plots are provided for this measurement since no significant deviations were recorded. 
- Location of

Thermocouple groups

Q Location of

Surface Thermocouples

$\Delta$ Location of Metal Deck and Concrete Deck Thermocouples
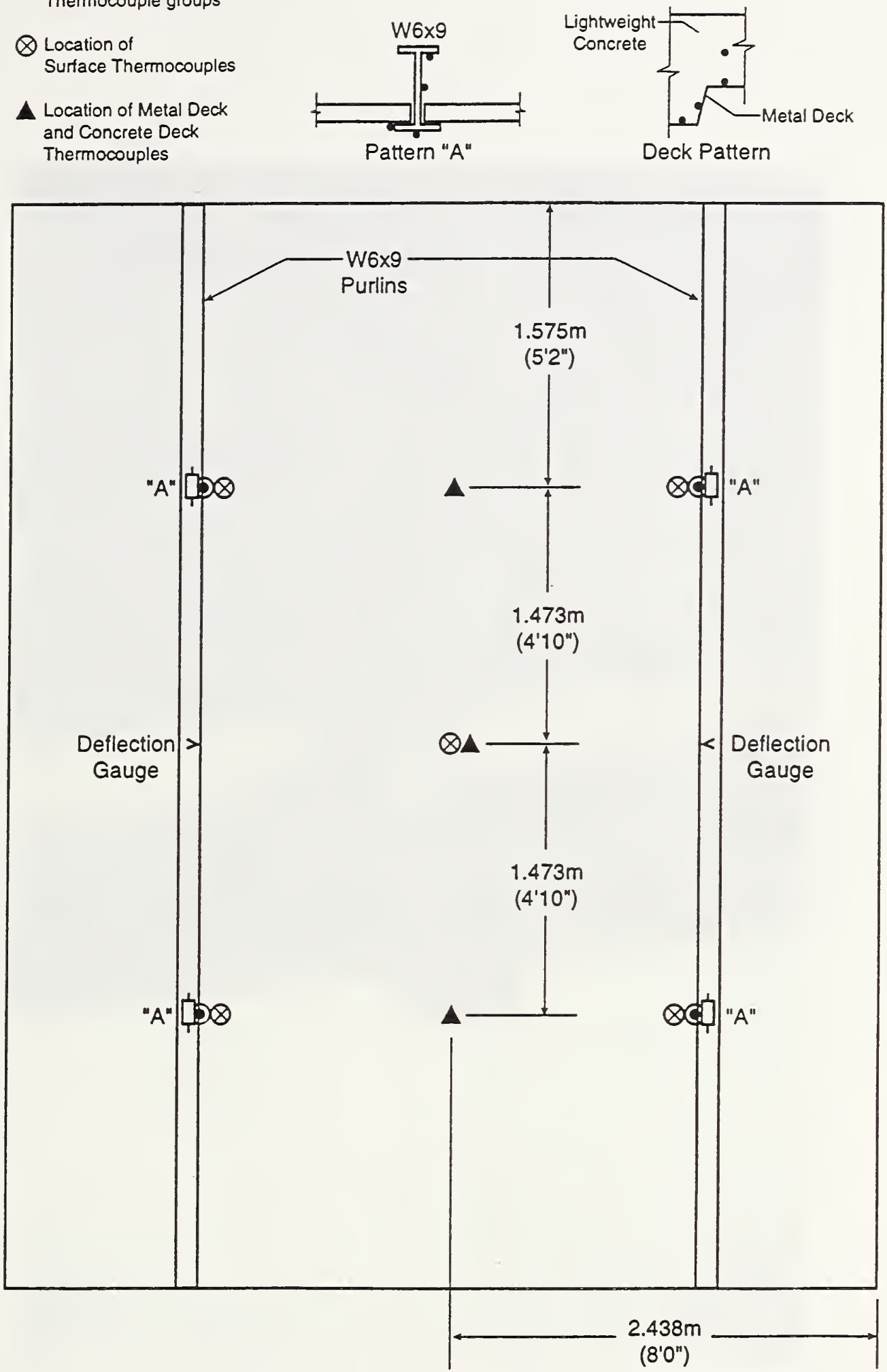

Figure B1. Thermocouple layout for W6x9 purlins, walk-on deck and deflection gauges 



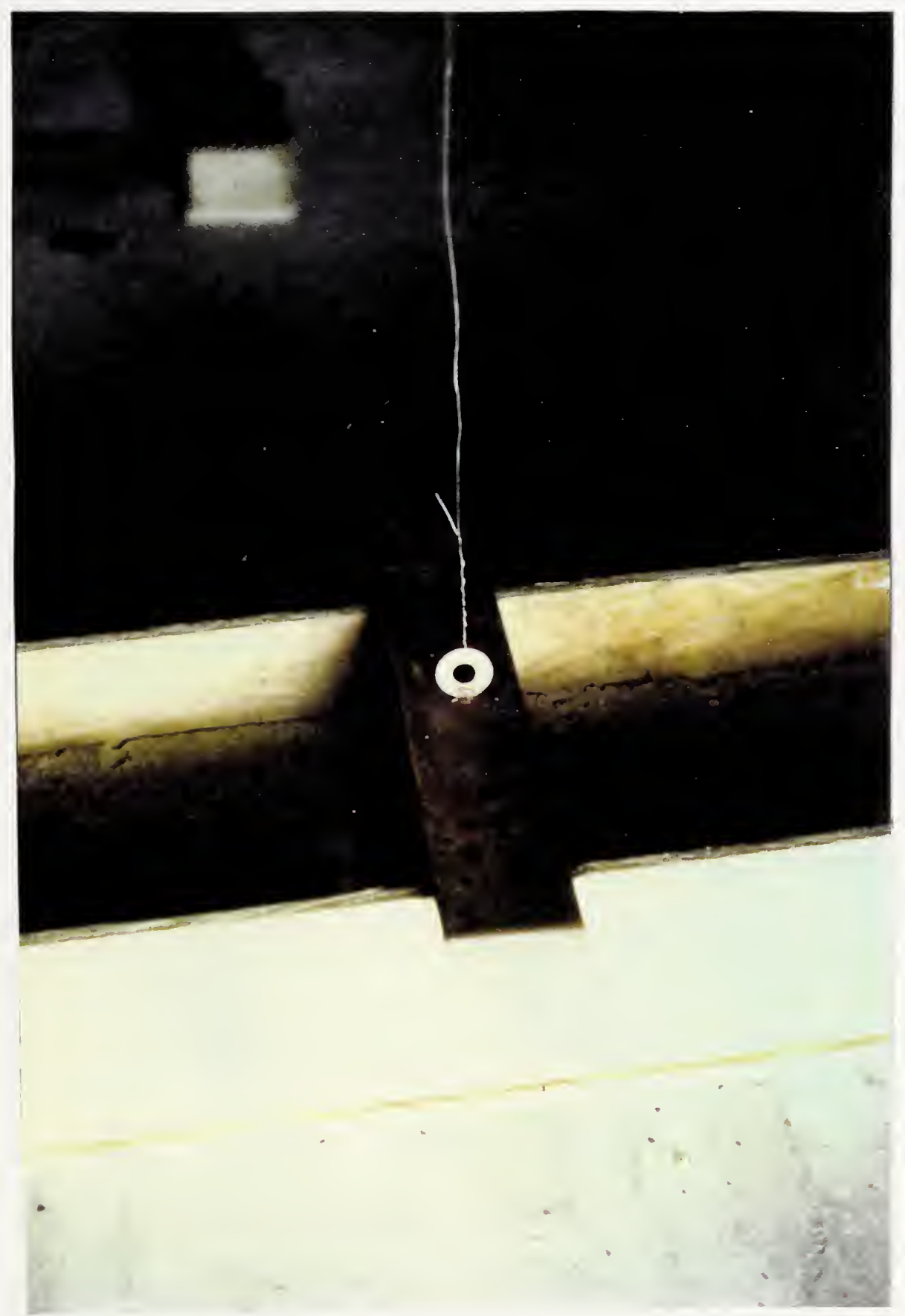

Figure B2. Photograph showing load bearing boxes and deflection gauge weight on purlin 



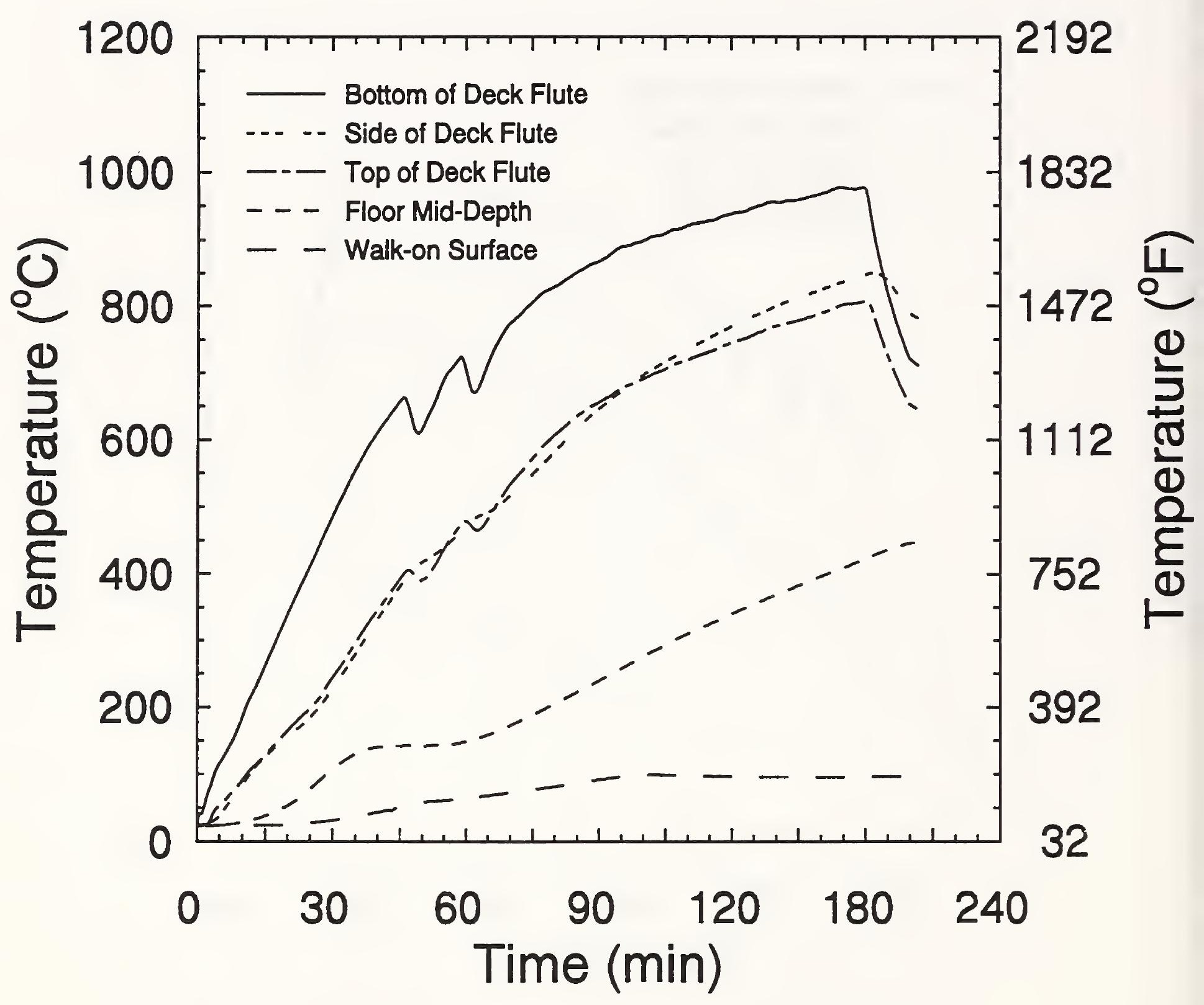

Figure B4. Concrete slab temperatures for walk-on deck, center location 


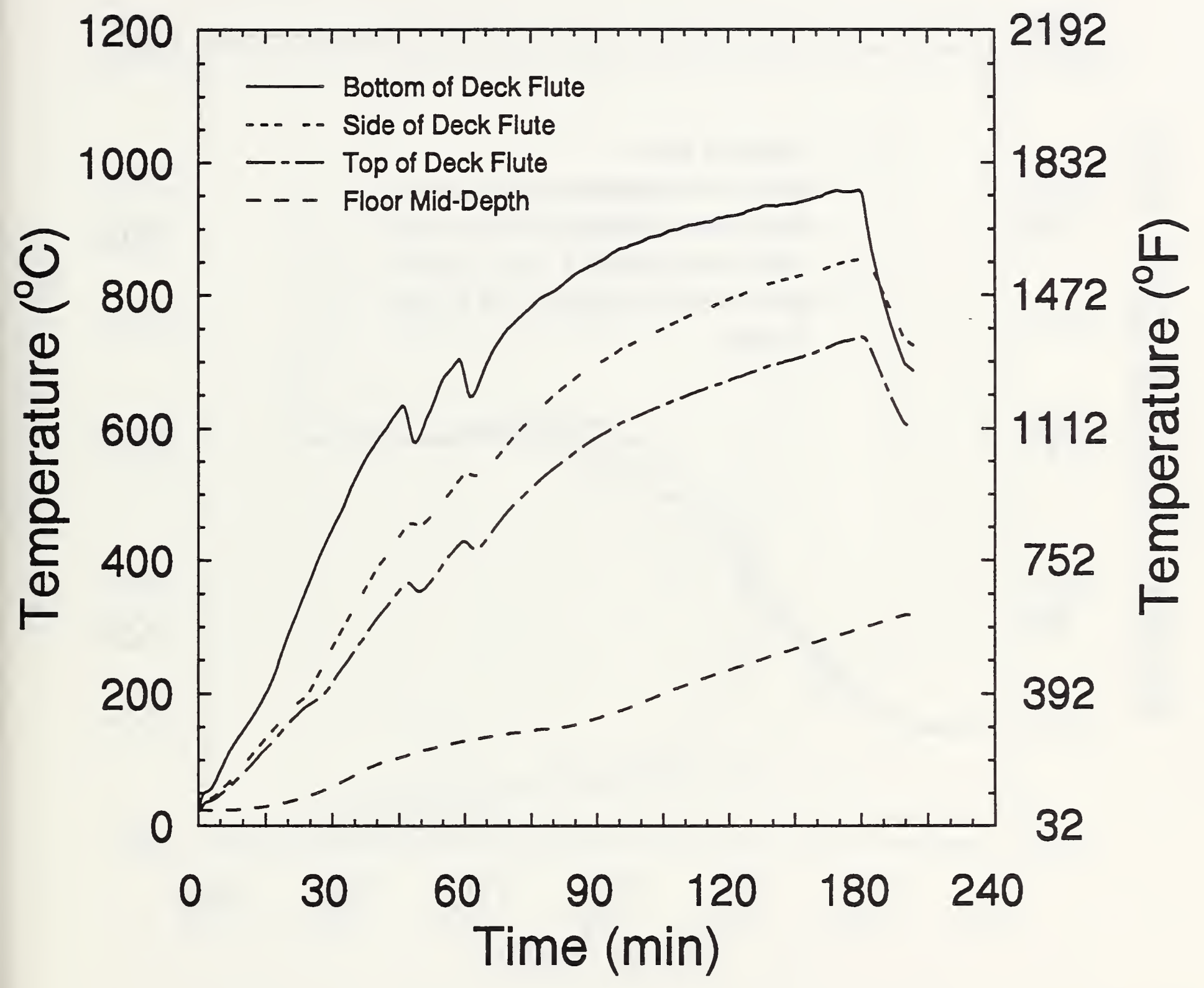

Figure B5. Concrete slab temperatures for walk-on deck, south end location 


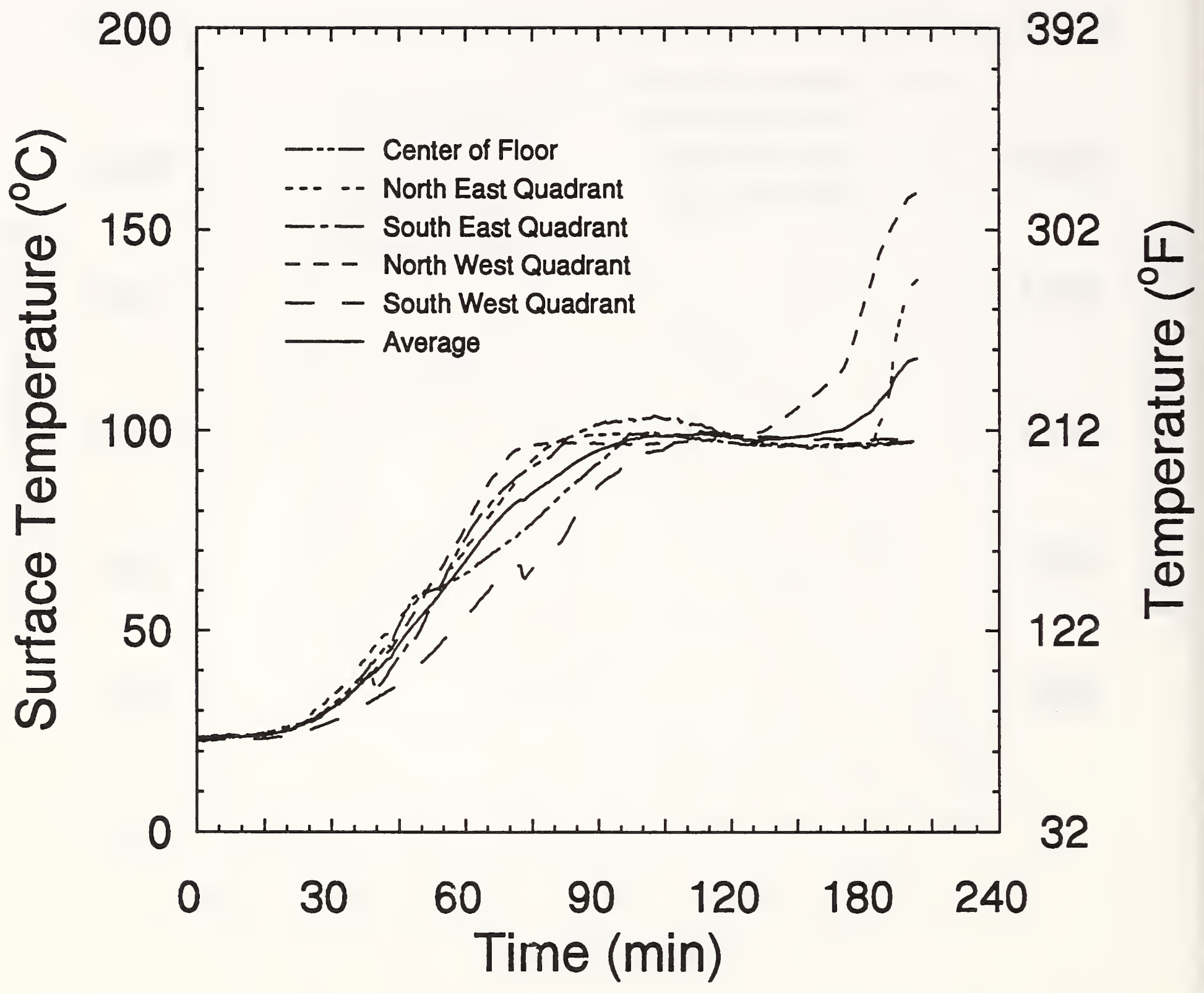

Figure B6. Walk-on deck surface temperatures 


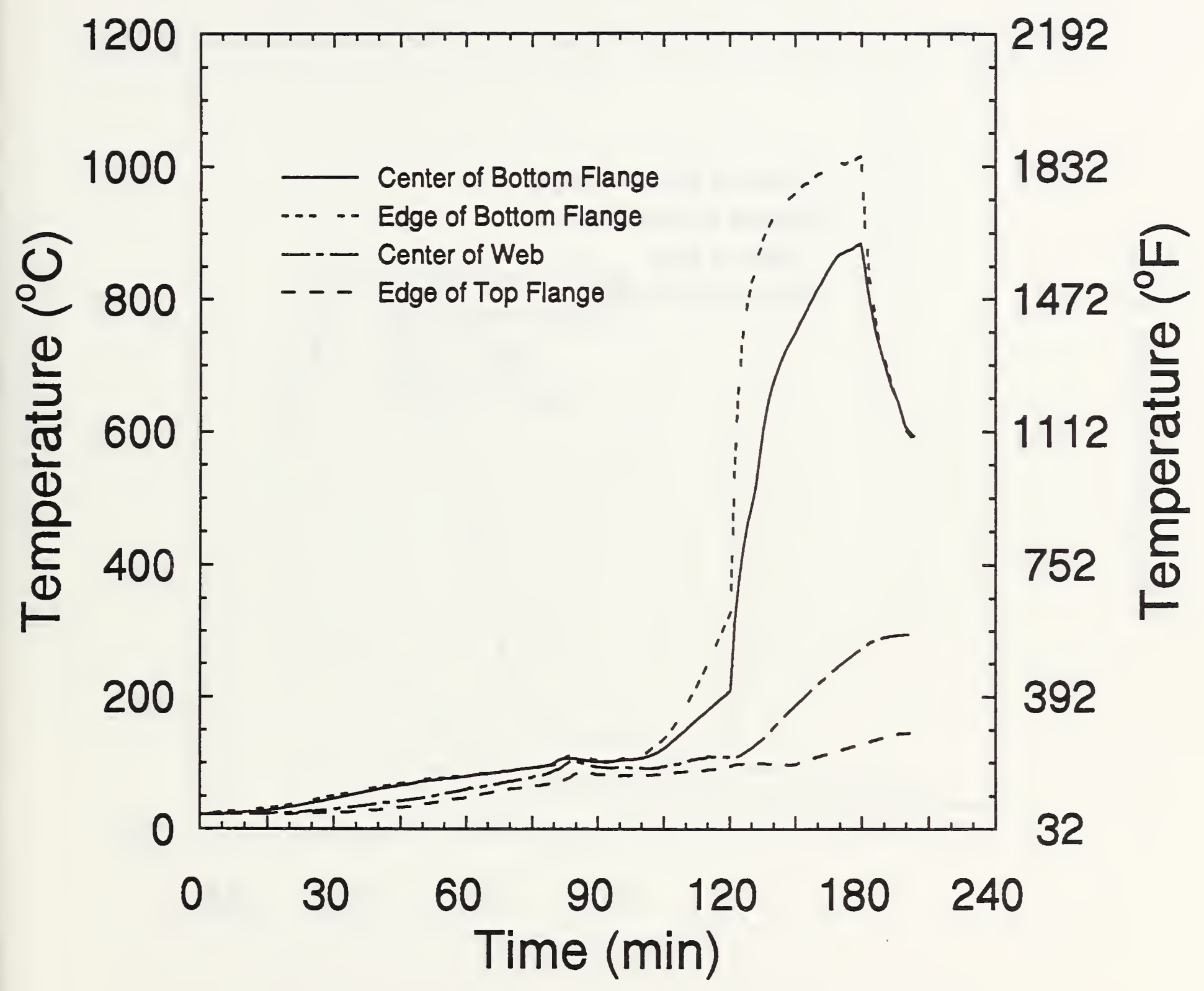

Figure B7. Temperatures on east purlin, north east quadrant location 


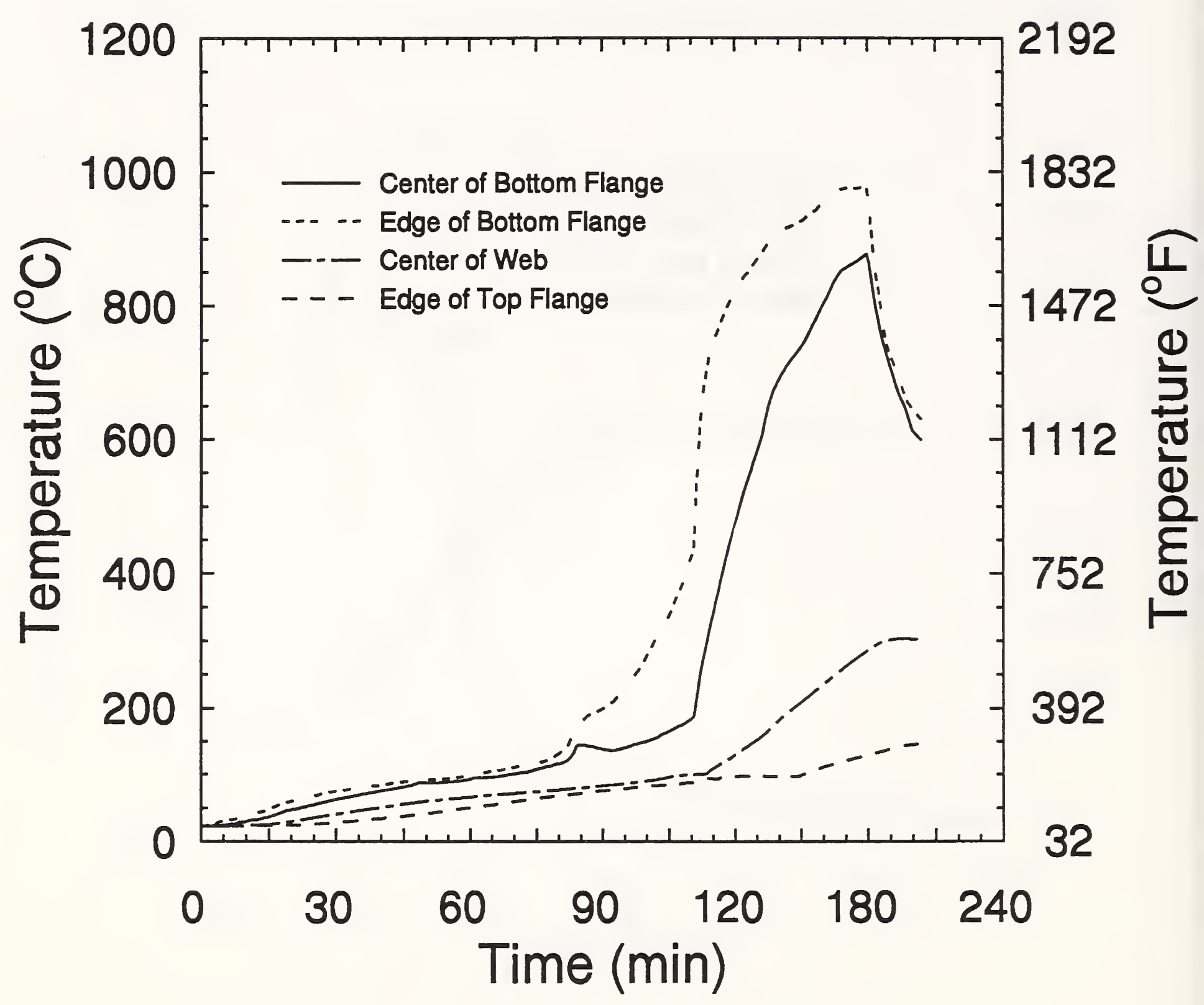

Figure B8. Temperatures on east purlin, south east quadrant location 


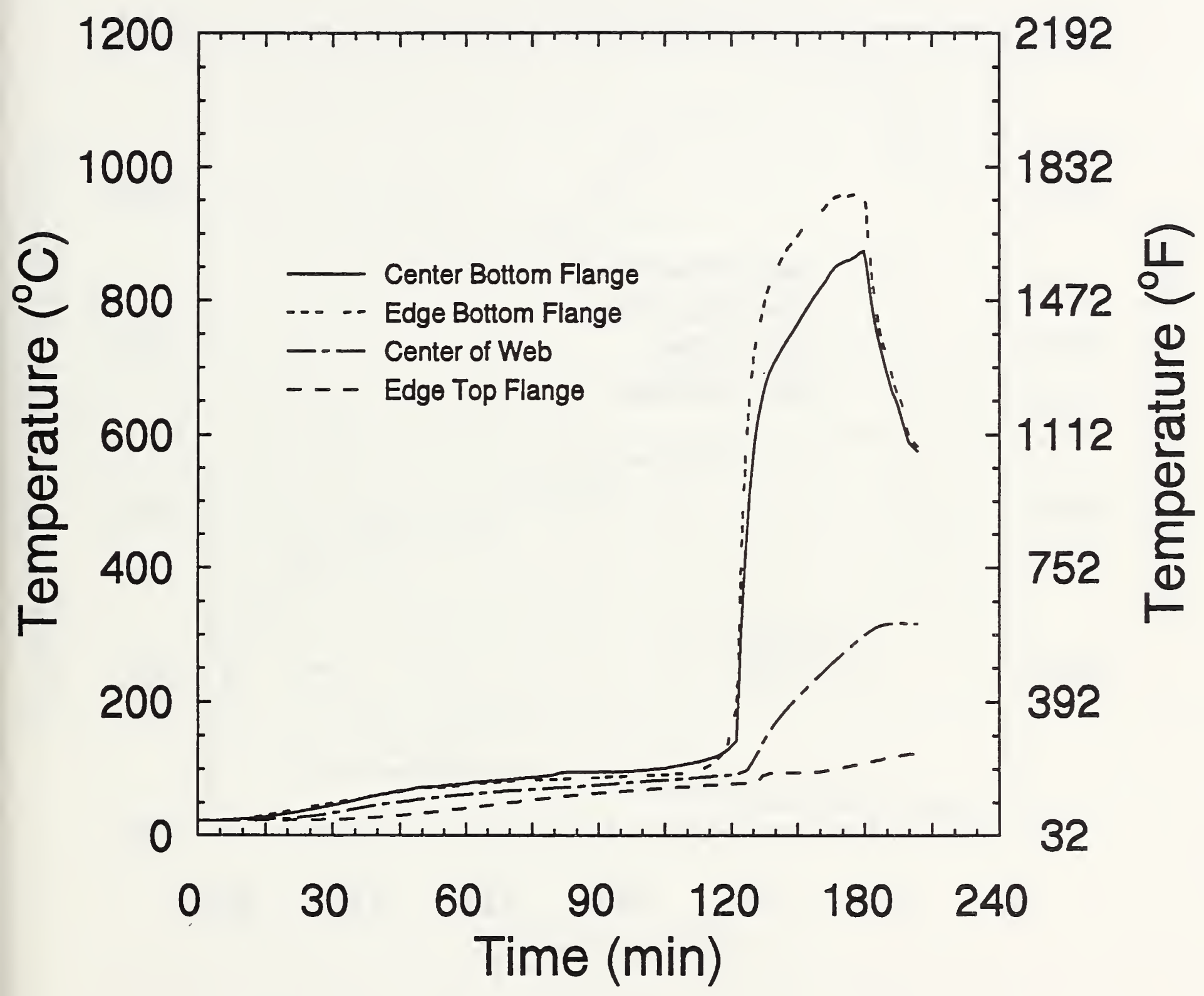

Figure B9. Temperatures on west purlin, north west quadrant location 


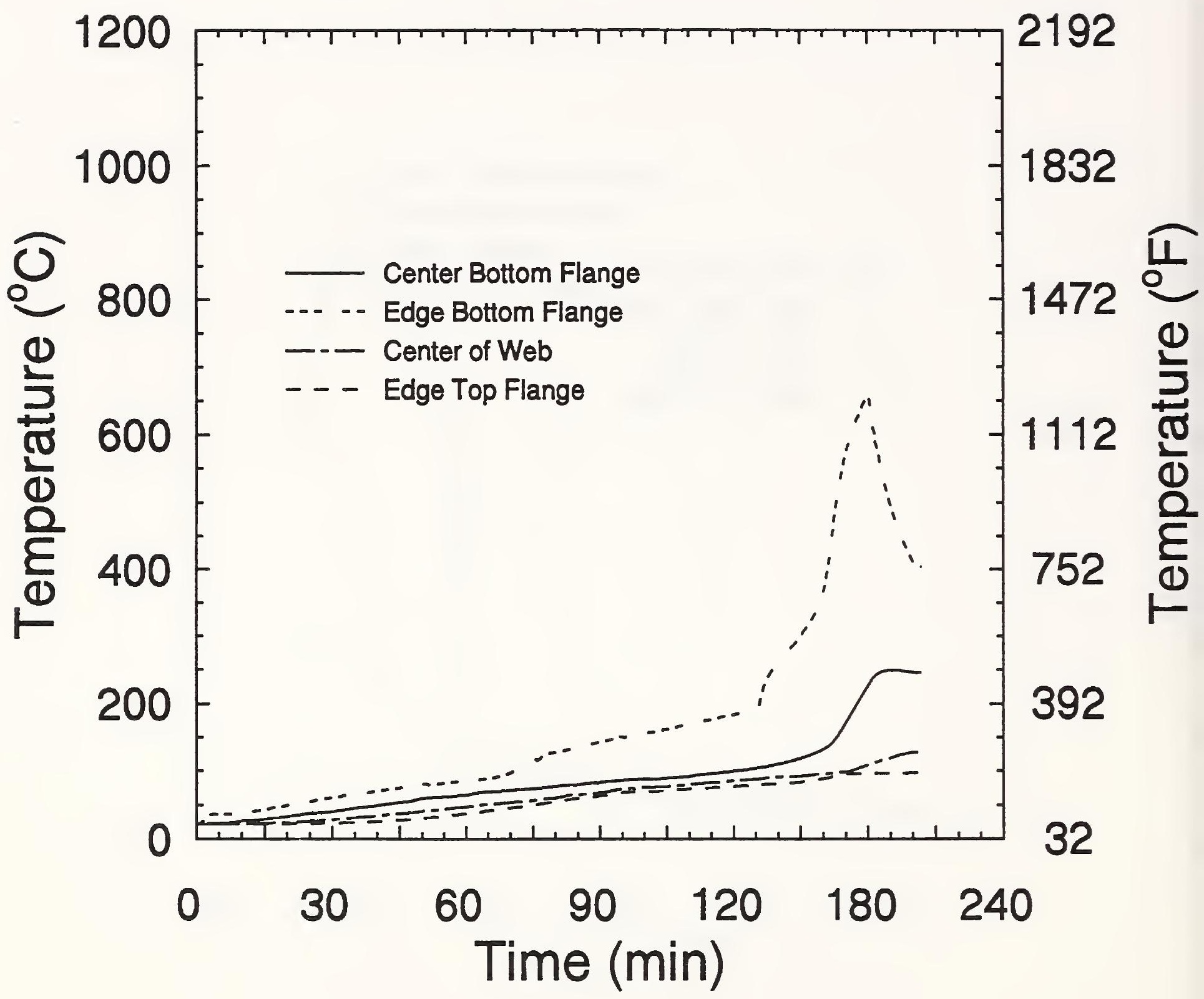

Figure B10. Temperatures on west purlin, south west quadrant location 


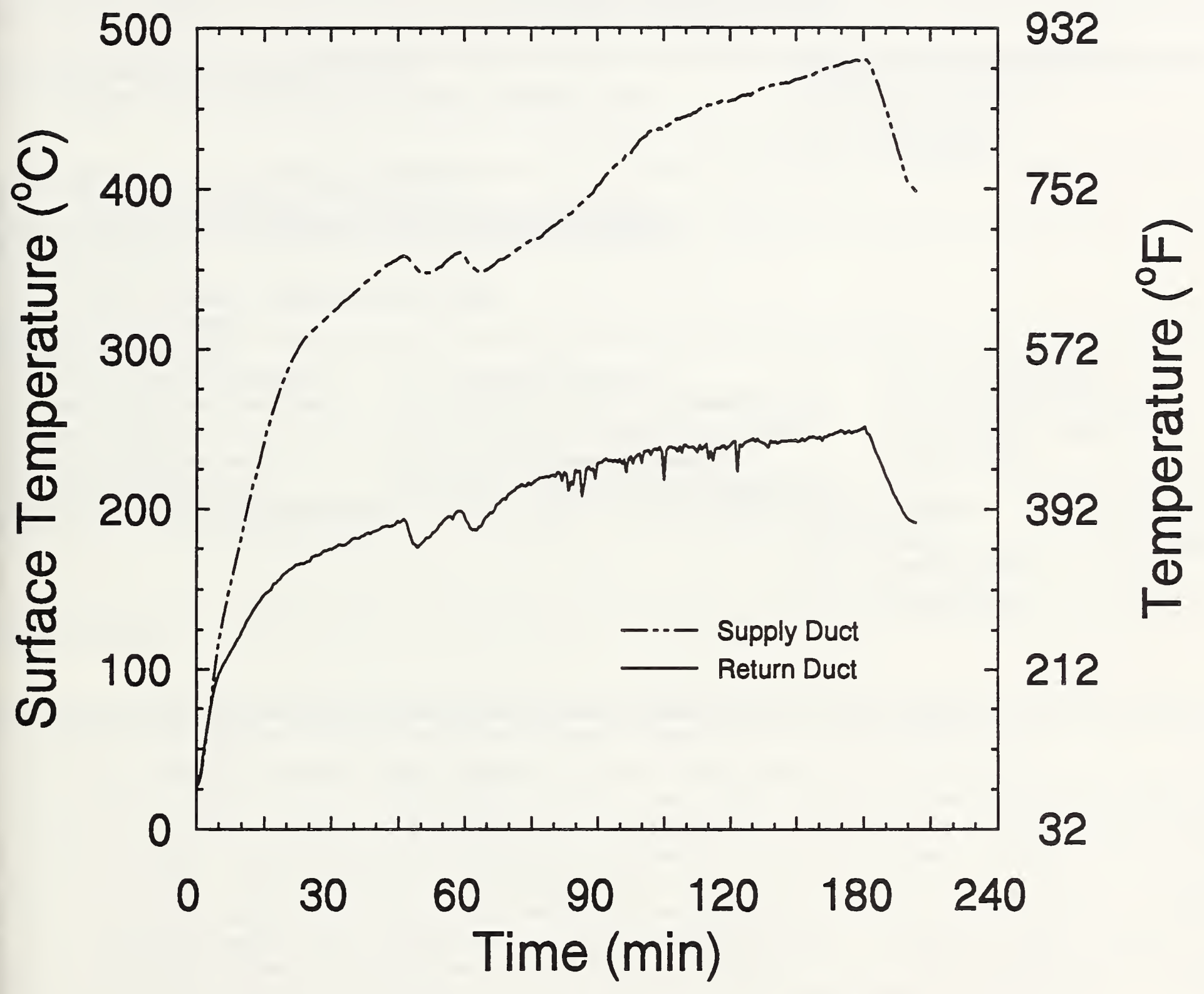

Figure B11. Surface temperatures on simulated air conditioning ducts 

NST-114

REV. 6-93)

ADMAN 4.09
U.S. DEPARTMENT OF COMMERCE

NATIONAL INSTITUTE OF STANDARDS AND TECHNOLOGY

\section{MANUSCRIPT REVIEW AND APPROVAL}

INSTRUCTIONS: ATTACH ORIGINAL OF THIS FORM TO ONE (1) COPY OF MANUSCRIPT AND SEND TO THE SECRETARY, APPROPRIATE EDITORIAL REVIEW BOARD

IITLE AND SUBTITLE (CITE IN FULL)

Fire Performance of an Interstitial Space Construction System

Lawson, J. Randall; Braun, Emil; DeLauter, Laurean; Roadarmel, Gary

\begin{tabular}{|l|l|}
\hline ERB CONTROL NUMBER & DIVISION \\
\hline $\begin{array}{l}\text { PUBLICATION REPORT NUMBER } \\
\text { NISTIR 5560 }\end{array}$ & CATEGORY CODE \\
\hline $\begin{array}{l}\text { PUBLICATION DATE } \\
\text { FE RUIATY 1995 }\end{array}$ & NUMBER PRINTED PAGES \\
\hline
\end{tabular}

(ERB USE ONLY)

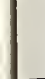

ABORATORY AND DIVISION NAMES (FIRST NIST AUTHOR ONLY)

Building and Fire Research Laboratory, Fire Safety Engineering Division

SPONSORING ORGANIZATION NAME AND COMPLETE ADDRESS (STREET, CITY, STATE, ZIP)

Medical Facilities Office

O.S. Army Corps of Engineers, HQUSACE CEMP-EM

Washington, DC 20314-1000

PROPOSED FOR NIST PUBLICATION

JOURNAL OF RESEARCH (NIST JRES)

J. PHYS. \& CHEM. REF. DATA (JPCRD)

HANDBOOK (NIST HB)

SPECIAL PUBLICATION (NIST SP)

TECHNICAL NOTE (NIST TN)

OPOSED FOR NON-NIST PUBLICATION (CITE FULLY)

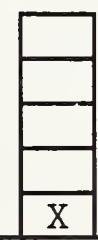

MONOGRAPH (NIST MN)

NATL. STD. REF. DATA SERIES (NIST NSRDS)

FEDERAL INF. PROCESS. STDS. (NIST FIPS)

LIST OF PUBLICATIONS (NIST LP) -

NIST INTERAGENCY/INTERNAL REPORT (NISTIR)
PERFORMING ORGANIZATION (CHECK (X) ONE BOX)

$X$ NIST/GAITHERSBURG

NIST/BOULDER

JILA/BOULDER

\section{pho}

\begin{tabular}{l|l|l|l}
\hline & U.S. & \\
& FOREIGN & PUBLISHING MEDIUM \\
\hline PAPER
\end{tabular}

DISKETTE (SPECIFY)

OTHER (SPECIFY)

LETTER CIRCULAR

BUILDING SCIENCE SERIES

PRODUCT STANDARDS

OTHER

\section{SUPPLEMENTARY NOTES}

ABSTRACT (A 2000-CHARACTER OR LESS FACTUAL SUMMARY OF MOST SIGNIFICANT INFORMATION. IF DOCUMENT INCLUDES A SIGNIFICANT BIBLIOGRAPHY OR ITERATURE SURVEY, CITE IT HERE. SPELL OUT ACRONYMS ON FIRST REFERENCE.) (CONTINUE ON SEPARATE PAGE, IF NECESSARY.)

A interstitial space building construction assembly consisting of a walk-on deck suspended from above by structural steel which also supported a functional floor, reproduce a design planned for use in a new hospital complex at Elmendorf Air Force Base, Alaska. This interstitial space assembly was built in the multi-story steel test structure at the National Institute of Standards and Technology. The construction assembly was tested by the same protocol used to evaluate the Veterans' Administration interstitial space construction assembly, tested in 1984. This protocol followed the National Fire Protection Association's NFPA 251 Fire Tests of Building Construction and Materials Standard, 1990 edition. Fire testing of the interstitial space system was carried out during the summer of 1994. This construction assembly met the requirements for a 2 hour fire endurance rating. The maximum surface temperature on the unexposed functional floor above the interstitial space reached $33^{\circ} \mathrm{C}\left(91^{\circ} \mathrm{F}\right)$ at the end of the two hour period. The maximum structural steel temperature inside the interstitial space was $123^{\circ} \mathrm{C}\left(253^{\circ} \mathrm{F}\right)$. The structural assembly was evaluated for a total of 2 hours and 30 minutes before the test was terminated.

KEY WORDS (MAXIMUM OF 9; 28 CHARACTERS AND SPACES EACH; SEPARATE WITH SEMICOLONS; ALPHABETIC ORDER; CAPITALIZE ONLY PROPER NAMES) fire endurance; fire tests; floor systems; interstitial spaces; structural systems UNLIMITED
ORDER FROM SUPERINTENDENT OF DOCUMENTS, U.S. GPO, WASHINGTON, DC 20402 ORDER FROM NTIS, SPRINGFIELD, VA 22161
NOTE TO AUTHOR(S): IF YOU DO NOT WISH THIS MANUSCRIPT ANNOUNCED BEFORE PUBLICATION, PLEASE CHECK HERE. 
